\title{
Extreme enrichment of Se, Te, PGE and Au in Cu sulfide microdroplets: evidence from LA-ICP-MS analysis of sulfides in the Skaergaard Intrusion, east Greenland
}

\author{
David A. Holwell ${ }^{1}$ Reid R. Keays ${ }^{2} \cdot$ Iain McDonald $^{3} \cdot$ Megan R. Williams $^{1,4}$
}

Received: 14 November 2014 / Accepted: 28 October 2015 / Published online: 25 November 2015

(C) The Author(s) 2015. This article is published with open access at Springerlink.com

\begin{abstract}
The Platinova Reef, in the Skaergaard Intrusion, east Greenland, is an example of a magmatic $\mathrm{Cu}-\mathrm{PGE}-\mathrm{Au}$ sulfide deposit formed in the latter stages of magmatic differentiation. As is characteristic with such deposits, it contains a low volume of sulfide, displays peak metal offsets and is $\mathrm{Cu}$ rich but $\mathrm{Ni}$ poor. However, even for such deposits, the Platinova Reef contains extremely low volumes of sulfide and the highest Pd and Au tenor sulfides of any magmatic ore deposit. Here, we present the first LA-ICPMS analyses of sulfide microdroplets from the Platinova Reef, which show that they have the highest Se concentrations (up to $1200 \mathrm{ppm}$ ) and lowest S/Se ratios (190-700) of any known magmatic sulfide deposit and have significant Te enrichment. In addition, where sulfide volume increases, there is a change from high Pd-tenor microdroplets trapped in situ to larger, low tenor sulfides. The transition between these two sulfide regimes is marked by sharp peaks in $\mathrm{Au}$, and then Te concentration, followed by a wider peak in $\mathrm{Se}$, which gradually decreases with height. Mineralogical
\end{abstract}

Communicated by Chris Ballhaus.

Electronic supplementary material The online version of this article (doi:10.1007/s00410-015-1203-y) contains supplementary material, which is available to authorized users.

David A. Holwell

dah29@le.ac.uk

1 Department of Geology, University of Leicester, University Road, Leicester LE1 7RH, UK

2 School of Geosciences, Monash University, Melbourne, VIC 3800, Australia

3 School of Earth and Ocean Sciences, Cardiff University, Park Place, Cardiff CF10 3YE, UK

4 Neftex, Milton Park, Oxfordshire OX14 4RY, UK evidence implies that there is no significant post-magmatic hydrothermal $\mathrm{S}$ loss and that the metal profiles are essentially a function of magmatic processes. We propose that to generate these extreme precious and semimetal contents, the sulfides must have formed from an anomalously metal-rich package of magma, possibly formed via the dissolution of a previously PGE-enriched sulfide. Other processes such as kinetic diffusion may have also occurred alongside this to produce the ultra-high tenors. The characteristic metal offset pattern observed is largely controlled by partitioning effects, producing offset peaks in the order $\mathrm{Pt}+\mathrm{Pd}>\mathrm{Au}>\mathrm{Te}>\mathrm{Se}>\mathrm{Cu}$ that are entirely consistent with published $\mathrm{D}$ values. This study confirms that extreme enrichment in sulfide droplets can occur in closed-system layered intrusions in situ, but this will characteristically form ore deposits that are so low in sulfide that they do not conform to conventional deposit models for $\mathrm{Cu}-\mathrm{Ni}-\mathrm{PGE}$ sulfides which require very high $\mathrm{R}$ factors, and settling of sulfide liquids.

Keywords Skaergaard - Platinum-group elements . Gold $\cdot$ Selenium $\cdot$ Sulfide saturation $\cdot$ Platinova Reef $\cdot S / S e$ ratios

\section{Introduction}

The Skaergaard Intrusion in east Greenland is host to the Platinova Reef, which is an example of a rare subclass of magmatic sulfide deposit, manifested as stratiform PGE reef deposits in the upper parts of the host intrusions (Brooks 1989; Bird et al. 1991; Andersen et al. 1998; Nielsen et al. 2005, Miller and Andersen 2002; Godel et al. 2014; Holwell and Keays 2014; Nielsen et al. 2015). These deposits differ from the more common disseminated and 
massive pyrrhotite-pentlandite-chalcopyrite ores found in the lower parts of layered mafic and ultramafic host intrusions, including along the margins and within conduits that feed larger intrusions (e.g., Maier 2005; Naldrett 2011 and references therein).

'Skaergaard-type' deposits have a number of characteristics that are a consequence of the late stage of sulfide saturation, which is often linked with magnetite crystallization (e.g., Maier et al. 2003; Prendergast 2000; Andersen 2006; Nielsen and Bernstein 2009; Holwell and Keays 2014; Keays and Tegner 2015). They are $\mathrm{Cu}$ rich and $\mathrm{Ni}$ poor, often Pd and Au dominant over Pt, show distinct offsets in peak metal concentrations and contain relatively low modal proportions of sulfide compared to many of the PGE reef deposits that typically occur in the lower portions of other intrusions (e.g., the Merensky Reef, Bushveld Complex, and the J-M Reef, Stillwater Complex). However, the metal tenors of the sulfides themselves can be very high. The Platinova Reef itself contains some of the highest Pd tenors of any magmatic sulfide deposit (average of $\sim 1 \mathrm{wt} \%$ Pd; Holwell and Keays (2014); and up to $60 \mathrm{wt} \%$; Godel et al. 2014). As such the Platinova Reef may represent an end member of this style of mineralization. While there are a number of common characteristics to all of these deposits, in detail, there are a great number of geochemical, mineralogical and stratigraphic variations and there is no current consensus on the magmatic and hydrothermal processes operating to explain all of these (e.g., Prendergast 2000; Andersen 2006; Nielsen and Bernstein 2009; Nielsen 2013; Holwell and Keays 2014; Godel et al. 2014; Nielsen et al. 2015; Keays and Tegner 2015).

In this paper, we provide the first in situ Laser AblationICP-MS study of the microdroplets of magmatic sulfide in the Platinova Reef of the Skaergaard Intrusion. We determine the chalcophile element contents of the sulfides, including their Se concentrations. From this, we determine the $\mathrm{S} / \mathrm{Se}$ ratios of sulfides through the reef section as this particularly useful geochemical indicator can be used as a proxy for sulfide-silicate interaction, metal enrichment and postmagmatic hydrothermal activity. We demonstrate that the Platinova Reef sulfides contain the highest Se concentrations and lowest $\mathrm{S} / \mathrm{Se}$ ratios of any recorded magmatic sulfide deposit, in addition to the highest known Pd and Au tenors. The results provide important constraints on models for the Platinova Reef and, more generally, the ability of magmatic sulfide systems within the upper parts of layered intrusions to become super-concentrated in chalcophile elements.

\section{Skaergaard-type magmatic sulfide deposits}

Stratiform reefs in the upper parts of their host layered mafic intrusions have been referred to by Maier (2005) as 'Stella-type' reefs after the deposits of Stella Intrusion in South Africa which have the highest PGE grades (10$15 \mathrm{ppm}$ ) of all such deposits (Maier et al. 2003); however, and following Miller and Andersen (2002), we refer to these as 'Skaergaard-type' deposits. Other similar, lowergrade deposits include those in the Sonju Lake intrusions within the Duluth Complex (Miller et al. 2002), the Rincon del Tigre intrusion in Bolivia (Prendergast 2000), the Coldwell Complex in Ontario, Canada (Barrie et al. 2002), the Kotelainen Intrusion, Finland (Mutanen 1997), and the Blue Draw Complex, South Dakota (Ciborowski et al. 2013).

\section{Triggers for sulfide saturation}

Sulfide saturation, and thus ore genesis, in these intrusions occurs late in their crystallization history and is triggered by prolonged fractionation of the magma, rather than the addition of external $\mathrm{S}$ via crustal contamination from local S-bearing country rocks, which is common in marginal and basal deposits (e.g., Li et al. 2002; Ripley et al. 2003; Keays and Lightfoot 2010). Mavrogenes and O'Neill (1999) demonstrated sulfide saturation can happen after more than $60 \%$ fractional crystallization of a basaltic magma. Consequently, these deposits are generally located in the upper third of their host intrusions. The late stage of sulfide saturation results in depletion of the compatible Ni into earlier formed silicates (particularly olivine) and oxides, whereas the incompatible $\mathrm{Cu}$ builds up in the magma such that the resultant sulfides are characteristically $\mathrm{Cu}$ rich and $\mathrm{Ni}$ poor.

In addition, the appearance of significant cumulus magnetite appears to have a control on the timing of sulfide saturation in many of these deposits. This is most obvious in the Rincon del Tigre and Stella intrusions where the mineralization is associated with thick magnetite layers (Prendergast 2000; Maier et al. 2003). Jenner et al. (2010) also demonstrated that magnetite crystallization can trigger sulfide saturation in arc magmas. Prolonged and enhanced magnetite crystallization lowers the $\mathrm{Fe}^{2+}$ activity of the melt, thus reducing its S-carrying capacity and triggering sulfide saturation (Maier 2005). Andersen (2006), Holwell and Keays (2014) and Keays and Tegner (2015) all suggest a link between magnetite and sulfide saturation, in the Skaergaard Intrusion.

\section{Characteristics}

The sulfide assemblages in Skaergaard-type deposits are primarily $\mathrm{Cu}$ rich and mixtures of bornite $\left(\mathrm{Cu}_{5} \mathrm{FeS}_{4}\right)$ and digenite $\left(\mathrm{Cu}_{9} \mathrm{~S}_{5}\right) /$ chalcocite $\left(\mathrm{Cu}_{2} \mathrm{~S}\right)$, without significant $\mathrm{Fe}$ sulfides. While it is clear the absence of $\mathrm{Ni}$ in the sulfide is due to its compatibility in earlier formed silicates, a number of explanations have been proposed to explain 
the $\mathrm{Cu}$-dominant sulfides including alteration of an original chalcopyrite-pyrrhotite assemblage (Andersen 2006) and magmatic oxidation (Wohlgemuth-Ueberwasser et al. 2013); both of these processes would lead to S loss. However, Ripley et al. (2002) demonstrated experimentally that the first sulfide liquid to segregate from strongly fractionated, previously S-undersaturated silicate melt can be very $\mathrm{Cu}$ rich. In addition, phase relationships in the $\mathrm{Cu}-\mathrm{Fe}-\mathrm{Pd}-\mathrm{S}$ system (Karup-Møller et al. 2008) indicate that the assemblage of $\mathrm{Pd}-\mathrm{Cu}$ alloys and bornite observed in the Platinova Reef may crystallize directly from a metal-rich sulfide melt.

The mineralized zones in the deposits are often characterized by offsets in metal peaks for $\mathrm{Pt}, \mathrm{Pd}, \mathrm{Au}$ and $\mathrm{Cu}$ at different stratigraphic heights (e.g., Rincon del Tigre, Stella and the Platinova Reef); Barnes et al. (1992) also reported metal offsets in the Munni Munni intrusion, Australia. In particular, the main PGE peaks in all of these deposits are generally below the main $\mathrm{Cu}$ peak; the latter of which marks an increase in bulk sulfide content. The metal offsets have been attributed by some to be due to the effects of $D_{\text {sul/sil }}$ values, with elements with higher D values concentrated into the earliest (lowest) layers (Prendergast and Keays 1989; Prendergast 2000; Holwell and Keays 2014); the effects of kinetic fractionation of metals (Mungall 2002); fractionation of the sulfide liquid during filter pressing (e.g., Andersen et al. 1998); and separation of and transport by a volatile- and Au-bearing residual of Fe-rich immiscible silicate melts (Rudashevsky et al. 2015; Nielsen et al. 2015).

The very low sulfide content of the deposits is a distinctive characteristic and a number of syn- and post-magmatic processes have been proposed to explain this; all of these processes involve some $\mathrm{S}$ loss and an increase in the metal tenor of the sulfides. Syn-magmatic S loss and an increase of metal tenor can occur through partial dissolution of the sulfide as proposed by Kerr and Leitch (2005). Dissolution of sulfide has been proposed to have occured in the Platinova Reef by Nielsen (2013), Godel et al. (2014), Holwell and Keays (2014) and Nielsen et al. (2015). Maier (2005) notes that sulfides associated with magnetite may have undergone late-magmatic $\mathrm{S}$ loss by $\mathrm{Fe}$ exchange with oxides through a similar process to that originally proposed by Naldrett and Lehmann (1987) for chomitites in the Bushveld Complex. Post-cumulus S loss by hydrothermal processes can also reduce bulk sulfide content, upgrade metal tenors and potentially redistribute metals and deposit them at redox boundaries (e.g., Andersen 2006).

\section{Geological setting of the Platinova Reef, Skaergaard Intrusion}

The Skaergaard Intrusion is a 7-km-wide mafic layered intrusion located on the eastern shore of the Kangerlussuaq
Fjord (Fig. 1a; Nielsen 2004; Svennevig and Guarnieri 2012; Salmonsen and Tegner 2013). It was emplaced at 56.02 Ma (Wotzlaw et al. 2012) during widespread Paleogene magmatic activity associated with the opening of the North Atlantic Ocean and passage of Greenland over the proto-Iceland plume (e.g., Brooks and Nielsen 1982; Tegner et al. 1998; Saunders et al. 1997; Momme et al. 2002). It crystallized under closed-system conditions from a single, homogenized magma body and is the type locality for igneous layering (e.g., Wager and Brown 1968; McBirney 1989; Irvine et al. 1998; Holness et al. 2007; Tegner et al. 2009; Thy et al. 2009; McKenzie 2011; Holness et al. 2011).

The Skaergaard Intrusion consists of three main units (Fig. 1b): the Layered Series, which crystallized from the floor up; the Upper Border Series, which is a mirrored sequence of the Layered Series that crystallized in situ from the roof down; and the Marginal Border Series that crystallized inwards from the outer walls of the intrusion (Wager and Deer 1939; Wager and Brown 1968; McBirney 1996; Irvine et al. 1998). The Layered Series consists of a Hidden Zone, mafic Lower, Middle and Upper Zones and a unit known as the Sandwich Horizon, which is the most differentiated unit of the Layered Series and occurs between it and the Upper Border Series (Fig. 1b).

Although PGE-rich cumulus sulfides first started to segregate from the Skaergaard magma at the base of Lower Zone c (Keays and Tegner 2015), the main mineralized unit; the Platinova Reef, is hosted by the Triple Group: a 100-m-thick unit of modally layered plagioclase-clinopyroxene-Fe-Ti oxide gabbros, located toward the top of the Middle zone (Andersen et al. 1998). Three prominent leucocratic layers are visible in the field that give the unit its name (L1-3; Fig. 1c), though a fourth also exists (L0; Fig. 1d) which marks the base of the mineralized unit. The gabbros of the Triple Group are made up of Fe-rich plagioclase, clinopyroxene and ilmenite/titanomagnetite (Wager and Brown 1968; Bird et al. 1991; Andersen et al. 1998; Tegner and Cawthorn 2010; Holness et al. 2011; Godel et al. 2014).

Sulfide mineralization is present as tiny $(<100 \mu \mathrm{m})$ grains of bornite-digenite/chalcocite intergrowths with associated precious metal-bearing minerals, which are dominantly $\mathrm{Pd}-\mathrm{Pt}-\mathrm{Au}-\mathrm{Cu}-\mathrm{Fe}$ alloys (Bird et al. 1991; Andersen et al. 1998; Rudashevsky et al. 2004; Cabri et al. 2005; Nielsen et al. 2005; McDonald et al. 2009; Godel et al. 2014; Rudashevsky et al. 2014, 2015; Nielsen et al. 2015). Figure $1 d$ shows the typical geochemical variations and offsets of base and precious metals through a generalized section of the Triple Group. Holwell and Keays (2014) devised a simplified zonation of the mineralization based on the dominant metals present, up through the Triple Group (Fig. 1d; shown with the Pd layers of Nielsen 

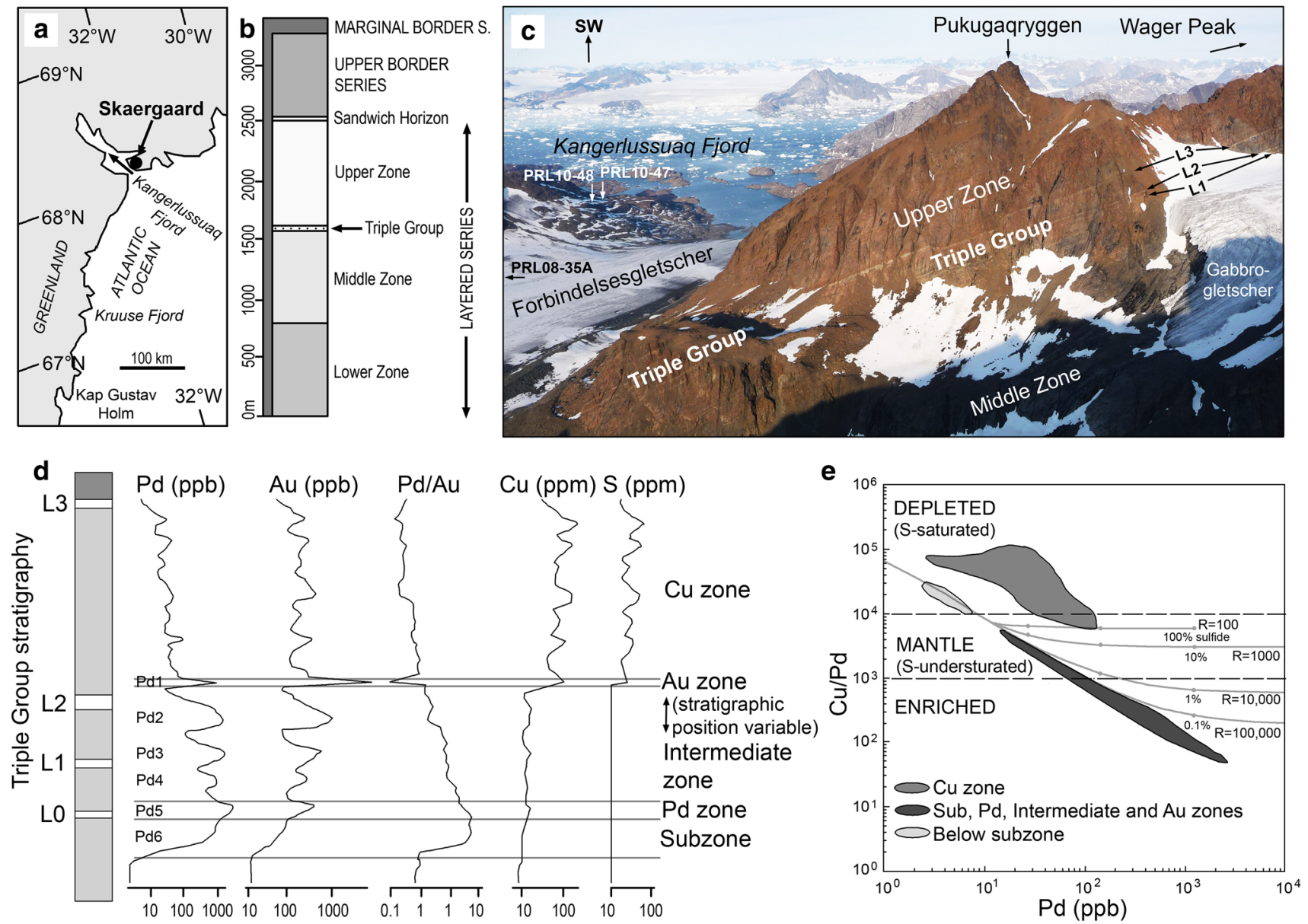

Fig. 1 Summary of geological and geochemical relationships within the Skaergaard Intrusion. a Location map of east Greenland; $\mathbf{b}$ schematic stratigraphic section of the Skaergaard Intrusion; c view of the Skaergaard Intrusion showing the Triple Group (100 m thick) that is host to the Platinova Reef; $\mathbf{d}$ representative profiles of bulk rock Pd, $\mathrm{Au}, \mathrm{Cu}, \mathrm{S}$ and $\mathrm{Pd} / \mathrm{Au}$ ratio with depth through a thick portion of the
Platinova Reef (central part of the intrusion), illustrating the simplified zonation defined by Holwell and Keays (2014) and the Pd horizons of Nielsen et al. (2005, 2015); e relationship between $\mathrm{Cu} / \mathrm{Pd}$ ratio and Pd content for rocks of the Platinova Reef after Holwell and Keays (2014). Note the distinct difference of the $\mathrm{Cu}$ zone samples

the Au zone varies in stratigraphic position across the intrusion, being closer to the Pd zone at the margins of the intrusion, but forming the outer edges of the lower-grade $\mathrm{Pd}$ layers within the Intermediate zone (Andersen et al. 1998; Nielsen et al. 2015). The clear geochemical differences in sulfide populations either side of the Au zone (Fig. 1e) are, however, consistent irrespective of where this transition occurs within the Triple Group.

\section{Sampling and methods}

Samples for this study were taken from two representative diamond drill holes drilled through the Triple Group of the Skaergaard Intrusion in 2008 and 2010 by Platina Resources Limited: PRL08-35A and PRL10-48. In PRL1048 , the Au zone is located $42 \mathrm{~m}$ above the Pd zone, whereas 
in PRL08-35A which is closer to the intrusion margins, the Au zone is just $7 \mathrm{~m}$ above the Pd zone. The former was chosen to show variations through a thick part of the reef, with samples selected from quarter core samples at 1-m intervals, and the latter to show detail through the Au zone itself, as samples were available at a $20-\mathrm{cm}$ resolution. In addition, a sample from the Upper Zone that contained sulfides up to $1 \mathrm{~mm}$ in diameter was analyzed, sourced from drill hole PRL10-47. Locations of the drill holes are given in Holwell and Keays (2014) and are shown in Fig. 1c.

Sulfide and precious metal mineralogy and textures were observed and documented in reflected light and by scanning electron microscope at the University of Leicester using a Hitachi S-3600N SEM, coupled with an Oxford Instruments INCA 350 energy dispersive $\mathrm{X}$-ray analysis system.

The trace element compositions of the sulfides were determined by laser ablation-inductively coupled plasmamass spectrometry (LA-ICP-MS) using a New Wave Research UP213 UV laser system coupled to a Thermo $\mathrm{X}$ Series 2 ICP-MS at Cardiff University. A total of 89 analyses were performed from 21 polished block samples. The relative abundances of PGE and other elements were recorded in time-resolved analyses mode using spot analyses. The beam diameter employed was $100 \mu \mathrm{m}$ to ensure total ablation of sulfide droplets that were consistently smaller than this; the laser beam operated a frequency of $10 \mathrm{~Hz}$ and a power of $\sim 6 \mathrm{~J} \mathrm{~cm}^{-2}$. Ablations were carried out under pure $\mathrm{He}$ (flow $\sim 0.7 \mathrm{~L} \mathrm{~min}^{-1}$ ), and the resulting vapor was combined with $\mathrm{Ar}$ (flow rate $0.65-0.75 \mathrm{~L} \mathrm{~min}^{-1}$ ) before delivery to the ICP-MS. Acquisitions lasted between 70 and $90 \mathrm{~s}$, including a 20 -s gas blank prior to the start of the analysis and a 10-s washout at the end. The following isotopes were measured or monitored: ${ }^{29} \mathrm{Si},{ }^{33} \mathrm{~S},{ }^{43} \mathrm{Ca}$, ${ }^{47} \mathrm{Ti},{ }^{51} \mathrm{~V},{ }^{57} \mathrm{Fe},{ }^{59} \mathrm{Co},{ }^{61} \mathrm{Ni},{ }^{65} \mathrm{Cu},{ }^{66} \mathrm{Zn},{ }^{68} \mathrm{Zn},{ }^{75} \mathrm{As},{ }^{82} \mathrm{Se}$, ${ }^{99} \mathrm{Ru},{ }^{101} \mathrm{Ru},{ }^{103} \mathrm{Rh},{ }^{105} \mathrm{Pd},{ }^{106} \mathrm{Pd},{ }^{108} \mathrm{Pd},{ }^{109} \mathrm{Ag},{ }^{111} \mathrm{Cd},{ }^{118} \mathrm{Sn}$, ${ }^{121} \mathrm{Sb},{ }^{125} \mathrm{Te},{ }^{185} \mathrm{Re},{ }^{187} \mathrm{Os},{ }^{189} \mathrm{Os},{ }^{193} \mathrm{Ir},{ }^{195} \mathrm{Pt},{ }^{197} \mathrm{Au},{ }^{209} \mathrm{Bi}$. Measurements of Si, S, Ca, Ti and V were effective proxies for the relative amount of sulfide $(\mathrm{S})$, oxide $(\mathrm{Ti}, \mathrm{V})$ and pyroxene/plagioclase ( $\mathrm{Si}, \mathrm{Ca}$ ) ablated, as the sulfides were hosted by $\mathrm{Fe}$-Ti oxides, pyroxene and plagioclase and the laser beam sampled a larger volume than that occupied by the sulfide droplet. The semimetals $\mathrm{As}, \mathrm{Sb}, \mathrm{Bi}, \mathrm{Te}$ and $\mathrm{Se}$ were measured as these elements can form platinum-group minerals (PGM), and thus, spikes in the detection of these elements that correspond with PGE can effectively identify PGM; no semimetal spikes are present where the PGE are present in solid solution in sulfide. The concentrations of each element within the sulfide droplets were determined assuming that any PGM identified had fractionated from the sulfide liquid and so were included in the time slice that was used. This method can produce slight overestimates of nuggety elements if they are hit by the laser beam and underestimates of PGE content will be produced if any PGM were polished away during sample preparation (c.f. Holwell et al. 2011).

Sulfur was used as the internal standard in the LA work. As all the sulfides were of a simple mineralogy of bornitedigenite intergrowths, a value of $23.7 \mathrm{wt} \% \mathrm{~S}$ was used as a 50-50 mix of bornite and digenite, which was confirmed to be representative using SEM-EDX analysis at the University of Leicester, with an error of $\pm 1 \mathrm{wt} \%$. An error of $1 \%$ in the S content will produce an error of $5 \%$ in the determination of other trace elements, which was deemed acceptable. Subtraction of gas blanks and internal standard corrections were performed using Thermo Plasmalab software. Calibration was performed using a series of 5 synthetic $\mathrm{Ni}-\mathrm{Fe}-\mathrm{S}$ standards prepared from quenched sulfides. The standards incorporate $\mathrm{S}, \mathrm{Ni}, \mathrm{Fe}$ and $\mathrm{Cu}$ as major elements and Co, Zn, As, Se, Ru, Rh, Pd, Ag, Cd, Sb, Te, Re, $\mathrm{Os}, \mathrm{Ir}, \mathrm{Pt}, \mathrm{Au}$ and $\mathrm{Bi}$ as trace elements, and the compositions of the 5 standards are given in Prichard et al. (2013). The standards produce five point calibration curves for $\mathrm{S}$, $\mathrm{Ni}$ and $\mathrm{Fe}$ and three point calibration curves for PGE, Ag, $\mathrm{Cd}, \mathrm{Re}, \mathrm{Au}$ and semimetals. Standards $1-3$ produce 3 point calibration curves for $\mathrm{Cu}, \mathrm{Co}$ and $\mathrm{Zn}$ and reliable matrixmatched corrections for argide species $\left({ }^{59} \mathrm{Co}^{40} \mathrm{Ar},{ }^{61} \mathrm{Ni}{ }^{40} \mathrm{Ar}\right.$, ${ }^{63} \mathrm{Cu}^{40} \mathrm{Ar},{ }^{65} \mathrm{Cu}^{40} \mathrm{Ar},{ }^{66} \mathrm{Zn}^{40} \mathrm{Ar}$ ) that interfere with ${ }^{99} \mathrm{Ru}$, ${ }^{101} \mathrm{Ru},{ }^{103} \mathrm{Rh},{ }^{105} \mathrm{Pd}$ and ${ }^{106} \mathrm{Pd}$. Corrections for ${ }^{106} \mathrm{Cd}$ on ${ }^{106} \mathrm{Pd}$ and ${ }^{108} \mathrm{Cd}$ on ${ }^{108} \mathrm{Pd}$ were determined using Cd-bearing Standard 1. Cd concentrations in the majority of sulfide inclusions were $<10 \mathrm{ppm}$, producing only very small corrections in most unknowns, but a small number of inclusions did contain $>100 \mathrm{ppm}$ of $\mathrm{Cd}$. Where independent corrections have been applied to different isotopes of the same element (e.g., ${ }^{66} \mathrm{Zn}^{40} \mathrm{Ar}$ and ${ }^{106} \mathrm{Cd}$ on ${ }^{106} \mathrm{Pd}$ and ${ }^{108} \mathrm{Cd}$ on ${ }^{108} \mathrm{Pd}$ ), the independently corrected values typically vary by less than $20 \%$ (and commonly $<5 \%$ ), indicating that the corrections are robust even where interfering elements are present at higher concentrations. The accuracy of the LAICP-MS procedure for PGE was checked by analysis of the Laflamme-Po724 standard run as an unknown against the Cardiff sulfide standards at the start and end of each day. These standard analyses are shown in Online Resource 1.

\section{Sulfide abundances, mineralogy and textures in the Platinova Reef}

Detailed descriptions of the mineralogy of the Platinova Reef can be found in Bird et al. (1991), Andersen et al. (1998), Rudashevsky et al. (2004), Cabri et al. (2005), Nielsen et al. (2005), Godel et al. (2014), Rudashevsky et al. (2014; 2015) and Nielsen et al. (2015). The latter compiles and summarizes a series of Geological Survey of Greenland and Denmark reports that record details of 
more than 4000 PGM (e.g., Nielsen et al. 2003; Rudashevsky et al. 2009). Therefore, in this paper, we simply present some of the relationships observed in our individual samples that have direct relevance to the interpretation of the laser ablation data presented below, and the reader is referred to the aforementioned papers for a comprehensive review.

\section{Host rock petrology}

The host rock Triple Group gabbros are made up of lathlike plagioclase, clinopyroxene, with some orthopyroxene after inverted pigeonite, and $\mathrm{Fe}-\mathrm{Ti}$ oxides made up of ilmenite and titanomagnetite. Olivine forms reaction rims around some of the oxide grains, as shown in Holness et al. (2011), Godel et al. (2014) and Nielsen et al. (2015). There is a large range in modal proportions of the major minerals. This is a function of the modal layering within the Triple Group, with the more leucocratic layers dominated by plagioclase at the expense of clinopyroxene and oxides. Sulfides in the Subzone, the Pd zone and the Intermediate Zone are very small (all are $<100 \mu \mathrm{m}$, but most $\sim 30 \mu \mathrm{m}$; Fig. 2), but in the $\mathrm{Cu}$ zone, the sulfides are more abundant and larger in size, typically 100-500 $\mu \mathrm{m}$ (Fig. 2a-c).

\section{Mineralogy of sulfide blebs}

The sulfides in all zones consist of a highly $\mathrm{Cu}$-rich, $\mathrm{Fe}$ poor assemblage of bornite $\left(\mathrm{Cu}_{5} \mathrm{FeS}_{4}\right)$ and digenite $\left(\mathrm{Cu}_{2} \mathrm{~S}\right) /$ chalcocite $\left(\mathrm{Cu}_{9} \mathrm{~S}_{5}\right)$ exsolution intergrowths (Fig. 2); however, one sample from the Pd zone (777 $\mathrm{m}$ in PRL10-48) contained only chalcopyrite (Fig. $2 \mathrm{~m}$ ), both as blebs at grain boundaries and as inclusions in oxide. This sample has abundant symplectites and olivine reaction rims around ilmenite of the type shown by Holness et al. (2011) and may indicate the presence of Fe-rich liquids that allowed for the formation of the more Fe-rich chalcopyrite. However, this is a very rare occurrence and Nielsen et al. (2015) note chalcopyrite only tends to occur as exsolutions in $\mathrm{Cu}$-rich sulfide or as the result of late alteration of bornite-rich assemblages.

The bornite-digenite assemblage is present in all other inclusions trapped in silicates and most of those trapped by $\mathrm{Fe}-\mathrm{Ti}$ oxides (e.g., Fig. 2c, i). A small proportion of sulfides trapped in $\mathrm{Fe}-\mathrm{Ti}$ oxide are composed of chalcopyrite and bornite (Fig. 21), which may reflect Fe exchange with the host sulfides (e.g., Naldrett and Lehmann 1987). As previously observed by Andersen et al. (1998), some of the sulfide droplets contain some low-Ti magnetite (Fig. 2c, f, j) and PGM. Previous studies by Bird et al. (1991), Andersen et al. (1998) Rudashevsky et al. (2004), Cabri et al. (2005), Nielsen et al. (2005; 2015 and references therein) and McDonald et al. (2009) have shown that for the main part of the Platinova Reef, the dominant PGM
Fig. 2 Mineralogical relationships of sulfides within the Platinova Reef, showing SEM backscattered electron images of sulfides and precious metal minerals from the $\mathrm{Cu}$ zone $(\mathbf{a}-\mathbf{c})$, the $\mathrm{Au}$ zone $(\mathbf{d}-\mathbf{f})$, the Intermediate zone $(\mathbf{g}-\mathbf{i})$, the Pd zone $(\mathbf{j}-\mathbf{m})$ and the Subzone $(\mathbf{n}-$ o). $p l$ plagioclase, $c p x$ clinopyroxene, $o x \mathrm{Fe}-\mathrm{Ti}$ oxide, $b n$ bornite, $d g$ digenite, $m t$ magnetite, $i l m$ ilmenite, ol olivine, amp amphibole, sul sulfide, cpy chalcopyrite

are the $\mathrm{Pd}-\mathrm{Cu}$ alloys skaergaardite $(\mathrm{PdCu})$ and nielsenite $\left(\mathrm{PdCu}_{3}\right)$ along with tetra-auricupride $(\mathrm{AuCu})$ in the $\mathrm{Au}$ zone. The $\mathrm{Au}$ content of the $\mathrm{Pd}-\mathrm{Au}-\mathrm{Cu}$ alloys increases with height (Andersen et al. (1998) in line with the upward bulk rock $\mathrm{Pd} / \mathrm{Au}$ ratio decrease (Fig. 1d). Silver has been identified as a minor component in some of the $\mathrm{Pd}-\mathrm{Au}-\mathrm{Cu}$ alloys (Nielsen et al. 2005). The margins of the intrusion are known to include a higher proportion of zvagintsevite $\left(\mathrm{Pd}_{3} \mathrm{~Pb}\right)$ and a host of other rarer PGM, including Te-, Asand Sb-bearing phases, unnamed $\mathrm{Au}_{3} \mathrm{Cu}$ and a number of Ag-bearing minerals (Nielsen et al. 2005; 2015).

A list of the precious metal minerals identified in our samples is presented in Table 1 . In addition to the $\mathrm{Pd}-\mathrm{Au}-\mathrm{Cu}$ alloy-dominant mineralogy, we also observed some sperrylite $\left(\mathrm{PtAs}_{2}\right)$ and $\mathrm{Pt}-\mathrm{Fe}$ alloys located at the margins of sulfide droplets in oxides (Fig. 2o) or silicates in the Subzone; in addition, some palarstanide $\left(\mathrm{Pd}_{5}(\mathrm{Sn}, \mathrm{As})_{2}\right)$ occurs in the $\mathrm{Pd}$ zones and some Pd-bearing telluride minerals, including keithconnite $\left(\mathrm{Pd}_{3} \mathrm{Te}\right)$, in the $\mathrm{Pd}$ and $\mathrm{Au}$ zones. Our samples from the lowest meter of the $\mathrm{Cu}$ zone contain some precious metal minerals, including Au-Pd alloys, Pd tellurides (Fig. 2b, c) and electrum (Au, Ag). Texturally, the PGM and Au-bearing minerals are located around the margins of the sulfide droplets (Figs. 2b-d, f, h, j, o) and occasionally as inclusions within the sulfide (Fig. 2e, i). It is notable that even when sulfide alteration has occurred, the PGM and Au minerals are still always associated with the sulfides (Fig. 2d, f).

\section{Textures of sulfide blebs}

Where trapped in Fe-Ti oxides, the sulfide droplets either take on the inverse crystal shape of the host (in titanomagnetite) or appear as rounded droplets in ilmenite (Fig. 2m), indicating trapping as a liquid (Fig. 2c, i, 1, o) as noted by Nielsen et al. (2005) and Godel et al. (2014). Where the droplets are trapped within clinopyroxene, a continuum of textures is seen between near-spherical (Fig. 2k) droplets to anhedral patches that appear to be controlled by the crystal structure and cleavage planes of the host clinopyroxene (Fig. 2h). In all examples of unaltered inclusions within clinopyroxene, the sulfide blebs have feathered margins with the feathering orientated in a common direction. The feathering is probably controlled by cleavage planes, although these do not necessarily correlate with exsolution lamellae, which are clearly seen to be orientated in a different direction (e.g., Fig. 2h, k). This is further evidence 

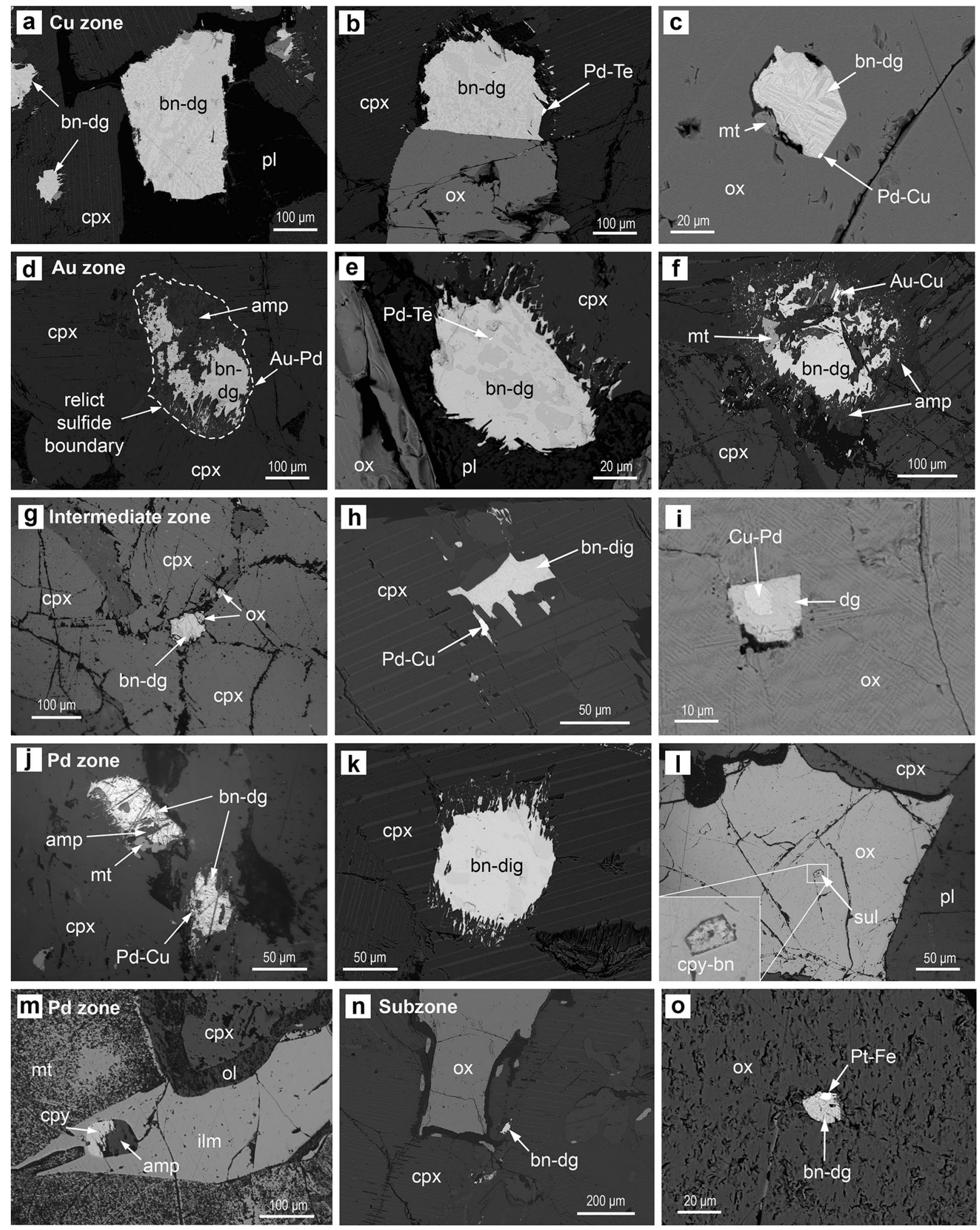
Table 1 Occurrences of precious metal minerals in our sample suite

\begin{tabular}{|c|c|c|c|c|c|c|c|}
\hline Mineral & Ideal formula & Subzone & $\begin{array}{l}\text { Pd } \\
\text { zone }\end{array}$ & $\begin{array}{l}\text { Inter. } \\
\text { zone }\end{array}$ & $\begin{array}{l}\mathrm{Au} \\
\text { zone }\end{array}$ & $\begin{array}{l}\mathrm{Cu} \\
\text { zone }\end{array}$ & Totals \\
\hline Tetra-auricupride & $\mathrm{AuCu}$ & & & & 3 & 5 & 8 \\
\hline Keithconnite & $\mathrm{Pd}_{3} \mathrm{Te}$ & & 2 & & & 4 & 6 \\
\hline Skaergaardite & $\mathrm{PdCu}$ & & 4 & & & 2 & 6 \\
\hline Electrum & $(\mathrm{Au}, \mathrm{Ag})$ & & 1 & & 2 & 2 & 5 \\
\hline Palarstenide & $\mathrm{Pd}_{5}(\mathrm{Sn}, \mathrm{As})_{2}$ & 1 & 3 & & & & 4 \\
\hline Sperrylite & $\mathrm{PtAs}_{2}$ & 3 & & & & & 3 \\
\hline Pt-Fe alloy & $(\mathrm{Pt}, \mathrm{Fe})$ & 3 & & & & & 3 \\
\hline \multicolumn{3}{|c|}{ Unconstrained $\mathrm{Pd}-\mathrm{Au}-\mathrm{Ag}-\mathrm{Cu}$ alloy } & 3 & & & & 3 \\
\hline Zvyagintsevite & $\mathrm{Pd}_{3} \mathrm{~Pb}$ & & 3 & & & & 3 \\
\hline Nielsenite & $\mathrm{Pd}_{3} \mathrm{Cu}$ & & & 2 & & & 2 \\
\hline Merenskyite & $\mathrm{PdTe}_{2}$ & & & & 2 & & 2 \\
\hline Kotulskite & PdTe & & & & 2 & & 2 \\
\hline Unconstrained & $\mathrm{Pd}-\mathrm{Cu}-\mathrm{As}-\mathrm{Sb}$ & & 2 & & & & 2 \\
\hline Sopcheite & $\mathrm{Ag}_{4} \mathrm{Pd}_{3} \mathrm{Te}_{4}$ & & & & & 1 & 1 \\
\hline Tulameenite & $\mathrm{PtFe}_{0.5} \mathrm{Cu}_{0.5}$ & & & & & 1 & 1 \\
\hline \multirow[t]{2}{*}{ Telluropalladinite } & $\mathrm{Pd}_{9} \mathrm{Te}_{4}$ & & & & & 1 & 1 \\
\hline & & & & & & & 52 \\
\hline
\end{tabular}

Note that precious metal minerals samples from the $\mathrm{Cu}$ zone are from samples within $1 \mathrm{~m}$ of the Au zone. Int. $=$ Intermediate

of trapping as liquid droplets, with some squeezed along cleavage planes in the host clinopyroxene. Sulfides present at grain boundaries are anhedral and interstitial to clinopyroxe and oxide grains (e.g., Fig. $2 \mathrm{~g}$, j). In the $\mathrm{Cu}$ zone, where sulfides are larger and more abundant (Fig. 2a), the textures of the sulfide blebs are more varied, but are generally subrounded. They are present as rounded blebs in all silicate mineral phases, including plagioclase (Fig. 2a), as subhedral blebs attached to the margins of oxides (Fig. 2b) and as inclusions in oxide minerals (Fig. 2c).

Alteration of the sulfides by secondary silicates is variable, with many sulfides showing no alteration whatsoever (e.g., Fig. 2h, k) and some showing minor to extensive alteration and replacement around the margins by hydrous silicates such as tremolite-actinolite and biotite (e.g., Fig. 2d-f, j). The PGM do not appear to be affected by this alteration, and $\mathrm{Au}$ - and PGE-bearing minerals remain in their original position within the sulfide droplet that has been overprinted by secondary silicates (Fig. 2b, f), or as satellite grains around the margins of where the sulfide boundary was before alteration (e.g., Fig. 2d).

\section{LA-ICP-MS analysis of sulfide droplets in the Platinova Reef}

Laser ablation-ICP-MS is one of the most effective and advanced tools in determining the fine scale mineralogy and composition of minerals in general, and the application to determining the base, precious and semimetal contents of
Fig. 3 Time-resolved analysis spectra of laser ablation analyses of sulfide droplets within the Platinova Reef and the Upper Zone, illustrating the presence of elements as solid solution (ss) or as PGE-Aubearing minerals. a Bornite from the Upper Zone; b bornite-digenite composite grain from $23 \mathrm{~m}$ above the base of the $\mathrm{Cu}$ zone; $\mathbf{c}$ bornite-digenite composite grain from the base of the $\mathrm{Cu}$ zone, with a $\mathrm{Pt}-\mathrm{Bi}-\mathrm{Te}$ mineral adjacent to a $\mathrm{Au}-\mathrm{Ag}-\mathrm{Pd}-\mathrm{Sb}$-bearing mineral. The reduction in $\mathrm{Cu}$ and increase in $\mathrm{Si}$ with time reflects more cpx being ablated relative to sulfide as the analysis progressed; $\mathbf{d}$ bornite-digenite composite grain from the base of the $\mathrm{Cu}$ zone, with a two precious metal minerals; e bornite-digenite composite grain from the Au zone, with a $\mathrm{Au}(+\mathrm{PGE})$-bearing mineral at the start of the analysis (surface of sample); $\mathbf{f}$ bornite-digenite composite grain from the Au zone, with a $\mathrm{Au}(+\mathrm{PGE})$-bearing mineral toward the end of the analysis where $\mathrm{Si}$ increases (PGM at bottom edge of ablated sulfide); $\mathbf{g}$ bornite-digenite composite grain from the Intermediate zone; $\mathbf{h}$ bornitedigenite composite grain from the Intermediate zone with a Pd-rich PGM; i bornite-digenite composite grain from the Pd zone with relatively large PGE and Au-bearing PGM; chalcopyrite grain from the Subzone with PGM. The peak in Pd and Au is offset from the peak in Pt-Bi-Te, showing two compositionally distinct PGM adjacent to each other

sulfide minerals has become a standard tool in characterizing magmatic sulfide ores (e.g., Ballhaus and Sylvester 2000; Holwell and McDonald 2007; Godel et al. 2007; Godel and Barnes 2008; Hutchinson and McDonald 2008; Dare et al. 2010; 2014; Holwell et al. 2011; Piña et al. 2013, Prichard et al. 2013; Smith et al. 2014). In addition to determining the bulk compositions of sulfides, the technique also allows for the identification of whether elements are present in solid solution, or as discrete minerals or microinclusions. This is possible as the analyses are done over a set time period (time-resolved analysis_-TRA), during which the laser 

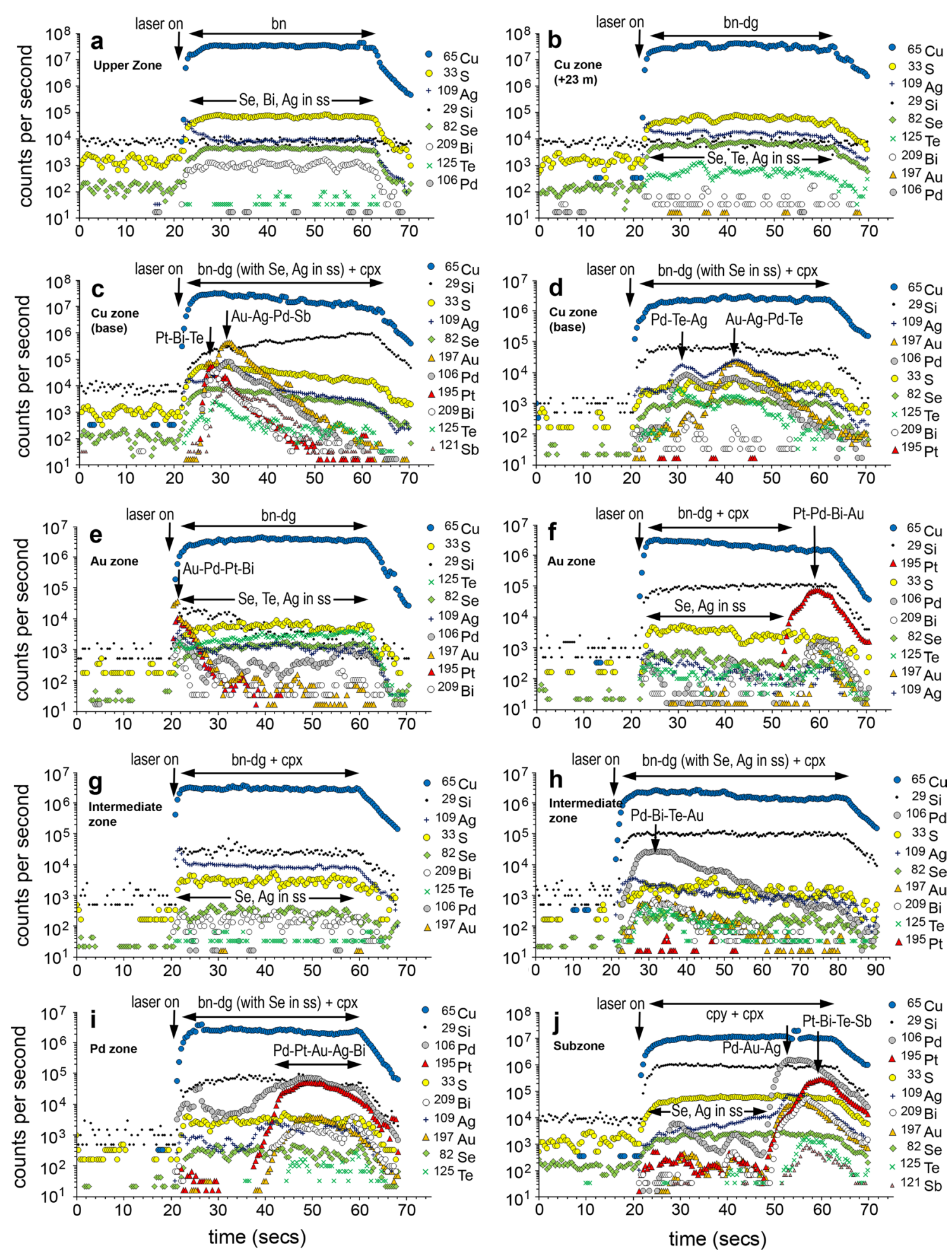

progressively ablates a trench across, or a pit down into, the sulfide mineral. As such, elements that are present in solid solution are recorded as smooth, regular profiles with time that typically mimic the major element profiles. Microinclusions of other minerals are recorded as small spikes in individual elements across the TRA profile. Typically, in magmatic sulfide

minerals, microinclusions are commonly PGM such as PGEbearing tellurides, bismuthides and arsenides (e.g., Holwell and McDonald 2007), which form due to the tendency for telluride, bismuthide, arsenide melts to separate from the sulfide liquid on cooling, sequestering PGE and forming PGM (e.g., Helmy et al. 2010, 2013a, b; Holwell and McDonald 2010). 
Eighty-nine sulfide blebs exposed on the surface of polished blocks were analyzed by LA-ICP-MS to determine the distribution and content of precious and semimetals in sulfides through the Platinova Reef. The analyses are representative of the sulfide population as a whole, with the vast majority hosted by clinopyroxene or at silicate-silicate or silicate oxide boundaries, and a few hosted entirely by Fe-Ti oxides. However, due to sectioning and polishing, inevitably some proportion of these sulfides has been lost (c.f. Holwell et al. 2011). Our analyses did, however, ablate the entirety of the remaining sulfide bleb by using a laser beam spot size greater than the bleb size. As such, the TRA profiles show the element deportment through the bleb, and the presence of any PGM. The element concentrations we report are representative of the ablated bleb as a whole and include the PGM on the assumption that they formed part of the original sulfide droplet.

\section{Element deportment in sulfide and other minerals}

Figure 3 shows a number of representative TRA spectra. Elements that mirror the profiles for $\mathrm{Cu}$ and $\mathrm{S}$ can be assumed to be present in solid solution in the sulfide. Selenium is one such element that will partition into solid sulfide phases (Helmy et al. 2010; Brenan 2015). However, elements such as $\mathrm{Te}, \mathrm{Bi}, \mathrm{Sb}$ and As that enter sulfide melt at high temperature may exsolve from the solid sulfide phase to form discrete minerals (e.g., Helmy et al. 2010). This distinction can be seen in Fig. 3j, with Se showing a smooth profile identical to that of $\mathrm{S}$ and $\mathrm{Cu}$, whereas Te, $\mathrm{Sb}$ and $\mathrm{Bi}$ show peaks toward the end of the ablation (from $50 \mathrm{~s}$ ) that coincide with precious metals peaks. Tellurium is also apparently present in solid solution in the $\mathrm{Cu}$ sulfide (Fig. 3b, e) in typical concentrations of around 50-100 ppm (Table 2), as well as being present in PGM (Fig. 3c, d, h, j). It is possible that even a smooth profile such as that shown by Te in Fig. 3e may be due to the presence of nanoparticles (as demonstrated for arsenides by Helmy et al. 2013a, b). However, this effect is more important on a nanometer or micron scale, and we utilized a $100-\mu \mathrm{m}$-diameter laser beam size and so if an element was present as nanoparticles, a smooth shape of the TRA profiles in Fig. 3 indicates its presence in a homogenous distribution within the sulfide on the scale of the laser beam, and as such, determination of concentrations from this data should still be representative of their bulk concentration regardless of the size of any individual particles. In the Upper Zone sample, $\mathrm{Bi}$ is also present in solid solution (Fig. 3a) in concentrations of around 2 ppm (Table 2).

A variety of PGM can be identified in the TRA data that correlate well with the recorded minerals listed in Table 1, as well as more generally with those listed by Nielsen et al. (2005, 2015). Figure 3c-f, h, j shows examples of analyses where at least one PGM was ablated with the sulfide bleb. It should be noted that a number of distinct PGM compositions can be picked out with offsets in element peaks (e.g., Fig. 3d, j). A typical PGM from the Pd zone is shown in Fig. 3i, containing Pd, Pt and Au. It is likely these PGM also contain $\mathrm{Cu}$ (e.g., skaergaardite) but as the host sulfide contains large amounts of these, the effect of these elements in PGM is not resolvable on the TRA spectra. A number of PGM containing $\mathrm{Pt}, \mathrm{Pd}, \mathrm{Au}$ and $\mathrm{Ag}$ with $\mathrm{Te}$ and $\mathrm{Bi}$ are shown in Fig. 3c, d, e, f, i.

\section{Element concentrations in sulfide microdroplets}

The concentrations of elements in the sulfides based on our LA-ICP-MS analysis are summarized in Table 2, with the full dataset for every inclusion listed in Table in Online Resource 1. The concentrations of elements that are in solid solution as defined above can be assumed to be representative of the droplet as a whole. In cases where some inclusions/PGM were present (e.g., Fig. 3c), we included the inclusions peaks and integrated these into a 'bulk' analysis of the droplet, which is based on the assumption that the original sulfide liquid droplet would have included the PGE and semimetals (either dissolved in sulfide liquid or as PGM that had been collected by the sulfide). As a result of the 'polishing effect' (Holwell et al. 2011), the measured PGE analyses are not truly representative of their concentration in the original sulfide droplet as some of the discrete mineral phases may have been lost or preferentially retained during sectioning, although the mean values may approach the true values (Holwell et al. 2011).

The mean concentrations of $\mathrm{Pd}, \mathrm{Ag}$, Se and $\mathrm{Te}$ in the sulfides from the various zones of the Platinova Reef are plotted together with $\mathrm{S} / \mathrm{Se}$ ratios in Fig. 4a-e. The scale is normalized to the mineralized stratigraphy (Subzone, $\mathrm{Pd}$ zone, Intermediate zone, $\mathrm{Au}$ zone and $\mathrm{Cu}$ zone) in the drill hole PRL10-48 and shown relative to the main Pd peak in the Pd zone at $777 \mathrm{~m}$ depth. The additional samples we analyzed from across the $\mathrm{Au}$ and $\mathrm{Cu}$ zone from PRL08$35 \mathrm{~A}$ have been placed at their equivalent positions in the $\mathrm{Au}$ and $\mathrm{Cu}$ zones, and the $\mathrm{Au}$ zone samples are also shown on a different scale to illustrate the variation at the $20-\mathrm{cm}$ resolution these samples allow (Fig. $4 \mathrm{f}-\mathrm{j}$ ).

\section{Precious metal concentrations}

The PGE and Au are present as PGM or Au-bearing minerals, rather than in solid solution, and therefore, their bulk contents in sulfides are less reliably determined by the LA-ICP-MS method. In some cases, the polishing effect is likely to have removed the PGM (or conversely, PGMpoor sulfide); however, when PGM were detected within the ablation, inclusion of the PGM in our determination of bulk 


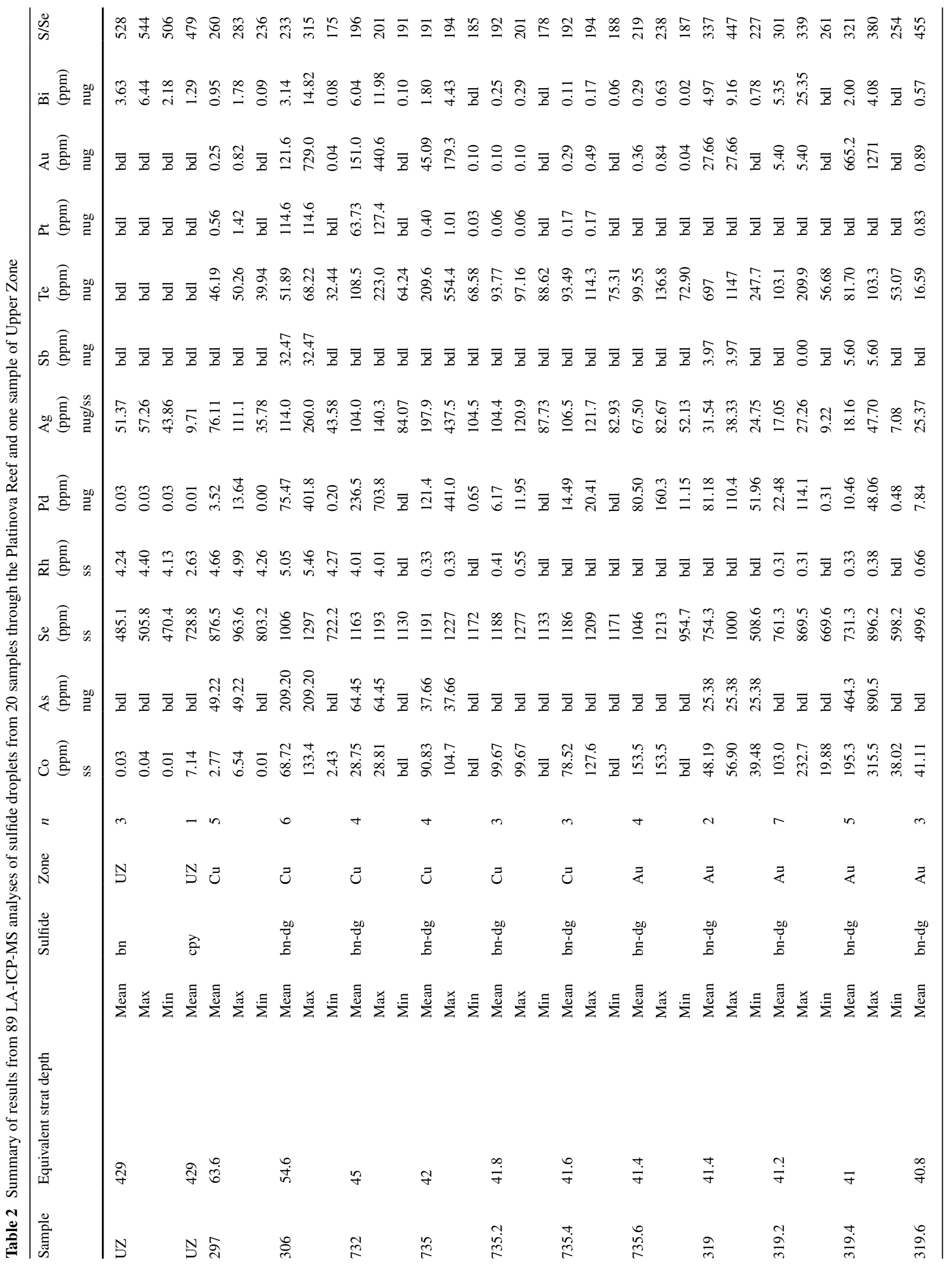




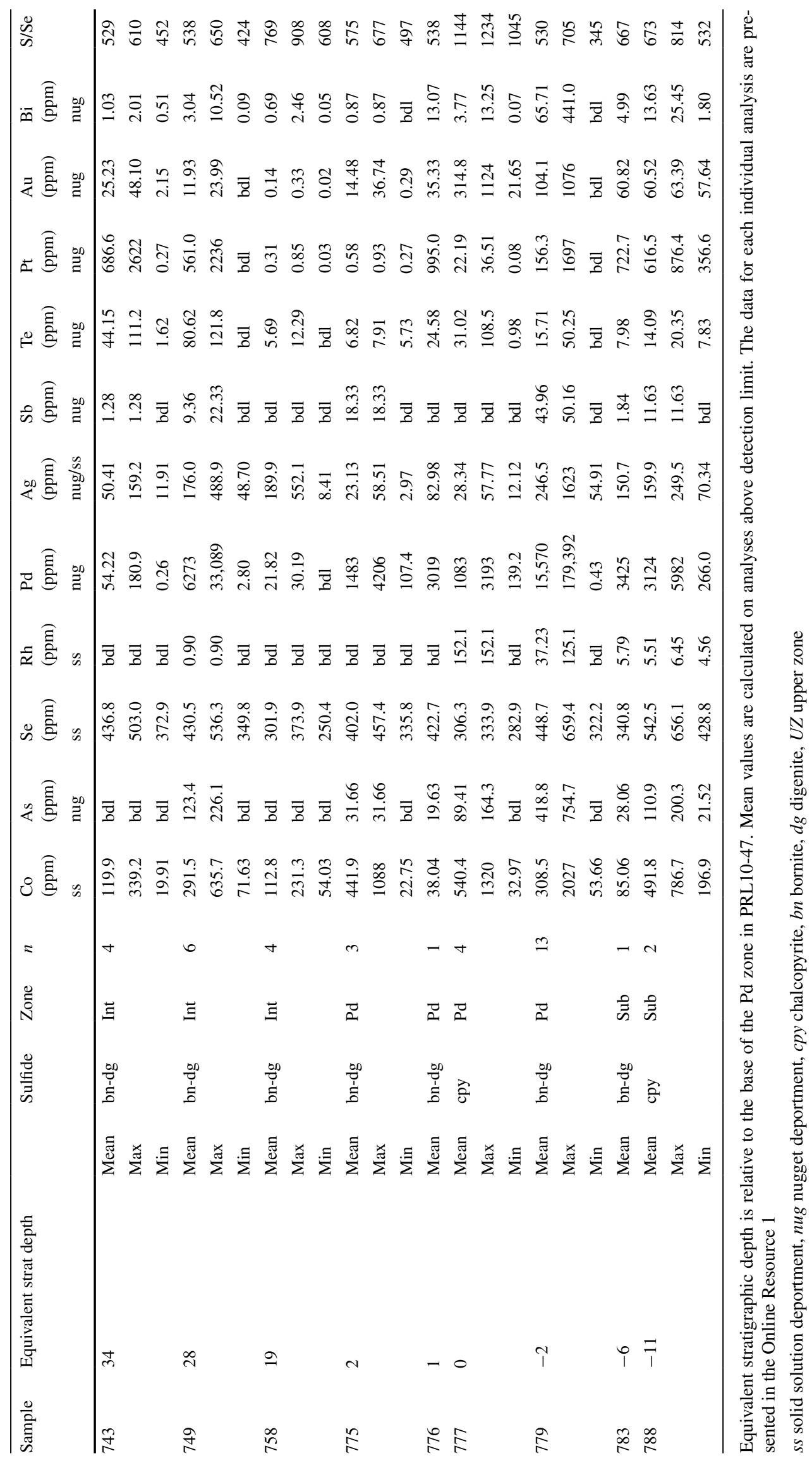




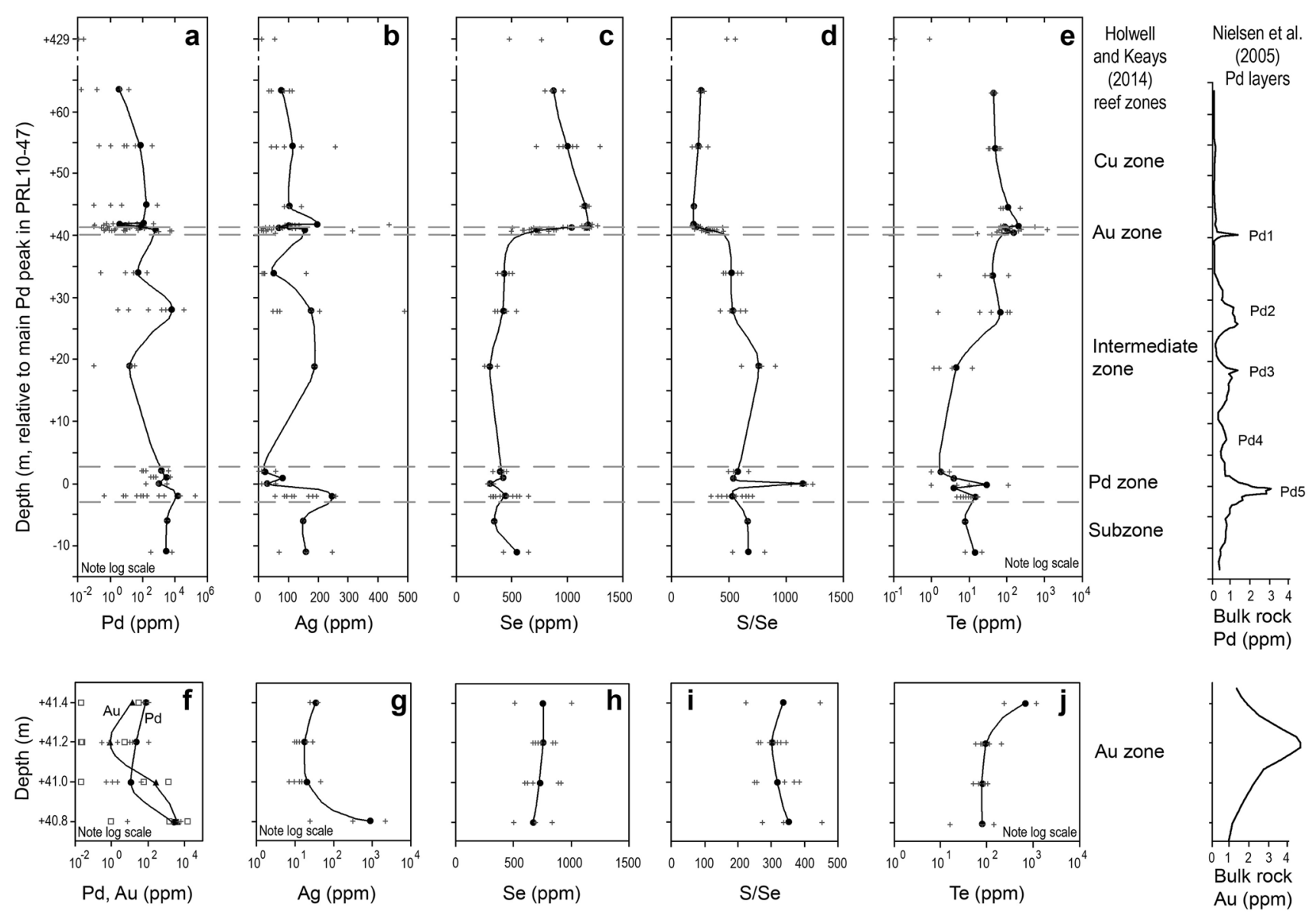

Fig. 4 Stratigraphic variations in a Pd concentration; b $\mathrm{Ag}$ concentration; c Se concentration; d S/Se ratio and e Te concentration within sulfide droplets through a representative section of the Platinova Reef. Vertical scale is relative to the Pd zone peak in PRL10-47 (777 m), with $\mathrm{Au}$ and $\mathrm{Cu}$ zone samples from PRL08-35A positioned

compositions gives values of 1000-20,000 ppm Pd (Table 2; Online Resource 1; Fig. 4a), very similar to those calculated from bulk rock by Holwell and Keays (2014). Figure 4a illustrates the wide range in Pd contents analyzed, which is to be expected due to the aforementioned effect. However, there is a clear reduction in the mean Pd tenor of the sulfides with height, from around $3000 \mathrm{ppm}$ in the Pd zone to less than $100 \mathrm{ppm}$ in the $\mathrm{Cu}$ zone. These are entirely consistent with those calculated from the bulk rock by Holwell and Keays (2014). Additionally, Table 2 and Fig. 4a also show a number of inclusions with very high Pd contents (up to 18 wt $\%$ in the Pd zone), which represent inclusions made up of a large proportion of PGM. Godel et al. (2014) calculated similar Pd contents for a number of PGM-rich sulfide blebs in their study. Gold tenors in the gold zone reach comparable concentrations (Fig. 4f; Table 2).

Silver is an example of an element present both in solid solution and also in discrete Ag-bearing minerals (e.g., Fig. 3c-e, i, j; Table 1). The mean concentrations of $\mathrm{Ag}$ relative to the Au zone. The bulk rock Pd values for PRL10-47 are shown on the right-hand side. Twenty-centimeter samples from the Au zone are also shown: f Pd and Au concentration; $\mathbf{g ~ A g}$ concentration; $\mathbf{h}$ Se concentration; $\mathbf{i}$ S/Se ratio and $\mathbf{j}$ Te concentration within sulfide droplets. Filled circles and solid lines indicate mean values

in sulfide droplets are highly variable within each sample, but generally range up to $200 \mathrm{ppm}$ Ag for samples from the Subzone, Pd and Intermediate zones (Table 2). The Au zone samples have a much tighter range in values (Table 2 , Fig. 4g). The Au zone actually has some of the lowest Ag contents in sulfide $(<50 \mathrm{ppm} \mathrm{Ag}$ in four out of five samples), possibly indicating $\mathrm{Ag}$ present in electrum or as tellurides (c.f. Table 1). Silver increases to almost $200 \mathrm{ppm} 1 \mathrm{~m}$ above the Au zone, then decreases gradually up through the lower parts of the $\mathrm{Cu}$ zone, with bornite and chalcopyrite in the Upper Zone containing 50 and $10 \mathrm{ppm} \mathrm{Ag}$, respectively (Table 2, Fig. 4b).

\section{Selenium concentrations and $\mathrm{S} / \mathrm{Se}$ ratios}

The concentrations of Se within sulfides from the same sample are remarkably consistent (Fig. 4c; Table 2), as seen by the much tighter range of data points compared with $\mathrm{Pd}$ and $\mathrm{Ag}$, for example. Figure $4 \mathrm{c}$ shows the range 
Fig. 5 Scatter plots showing the relationship between a Se and $\mathrm{Ag} ; \mathbf{b}$ Se and $\mathrm{Te} ; \mathbf{c} \mathrm{Se}$ and $\mathrm{Bi}$; and $\mathbf{d ~} \mathrm{Bi}$ and $\mathrm{Te}$
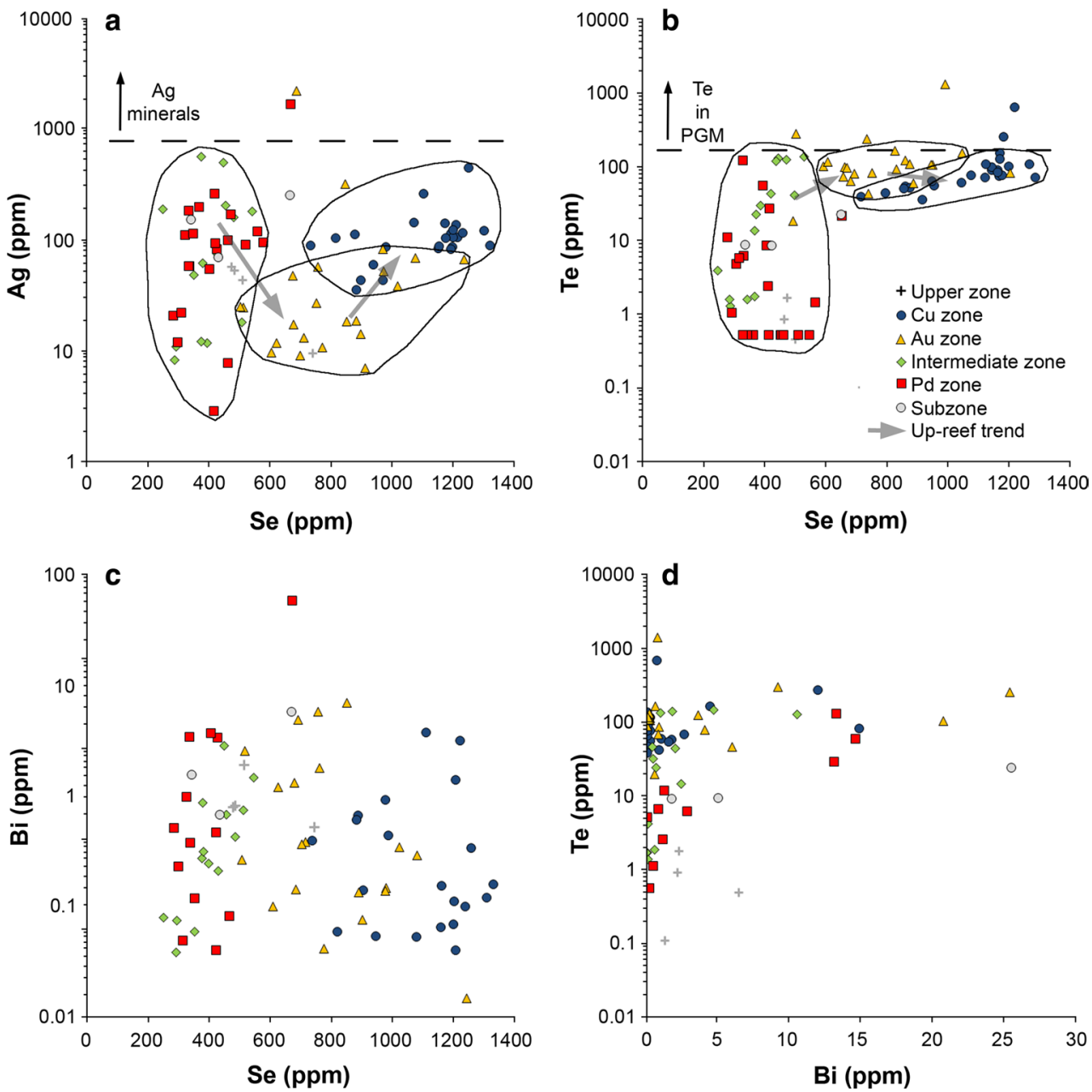

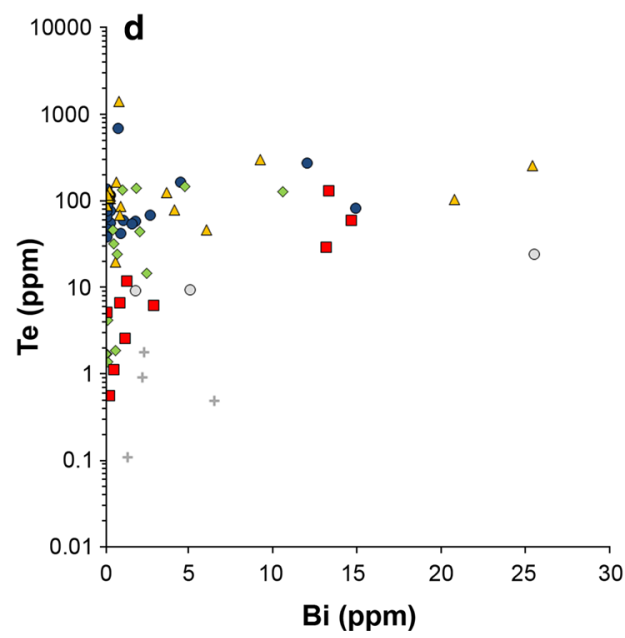

in Se contents in the various zones, with a striking shift to much higher values at the Au zone. The sulfide droplets of the Subzone, Pd zone (including the chalcopyrite) and Intermediate zone have very consistent Se contents of around 300-500 ppm. The Se contents of the sulfides rise to $\sim 750 \mathrm{ppm}$ in the Au zone (and continues to rise through the Au zone; Fig. 4h) reaching 1000-1200 ppm Se in the basal portions of the $\mathrm{Cu}$ zone (Fig. 4c). There is a remarkably smooth decrease in the Se content of the sulfides upwards to a value of 870 ppm $30 \mathrm{~m}$ away from the base of the $\mathrm{Cu}$ zone (Fig. 4c). Chalcopyrite and bornite in the Upper zone sample contain $\sim 700$ and 500 ppm Se, respectively (Table 2). The Se contents of the sulfides peak at the base of the $\mathrm{Cu}$ zone, not in the Au zone, thus illustrating a further metal offset in the profile. Figure 5a illustrates the relationship between $\mathrm{Se}$ and $\mathrm{Ag}$, with three distinct groupings representing the main parts of the reef (Subzone, Pd zone and Intermediate zone). The progressive increase in Se content up through the reef is marked by a distinct dip in the average Ag content in the Au zone (Fig. 4b).

The in situ $\mathrm{S} / \mathrm{Se}$ ratios are primarily affected by the concentration of $\mathrm{Se}$ in the sulfide given that the $\mathrm{S}$ content has negligible variance due to the uniformity of the mineralogy (except the chalcopyrite-only assemblages). The Subzone, $\mathrm{Pd}$ and Intermediate zones have $\mathrm{S} / \mathrm{Se}$ ratios typically in the region of 400-800 (Fig. 4d), although the chalcopyrite inclusions in one sample from the $\mathrm{Pd}$ zone have higher $\mathrm{S} /$ Se ratios of around 1200. Their Se contents are similar to those of the bornite-digenite assemblages in other Pd zone samples (Fig. 4c; Table 2), though the lower S concentration of chalcopyrite means their $\mathrm{S} / \mathrm{Se}$ ratio is therefore much higher. The $\mathrm{Au}$ zone has sulfides with $\mathrm{S} / \mathrm{Se}$ ratios of $\sim 300-350$ (Fig. 4i) and the base of the $\mathrm{Cu}$ zone $\sim 190$, which rises gradually and smoothly with distance from the base of the $\mathrm{Cu}$ zone (Fig. 4d), with our sample from the Upper Zone having a S/Se ratio of $~ 520$ in bornite, and 470 in chalcopyrite (Table 2). The Platinova Reef therefore has the lowest $\mathrm{S} / \mathrm{Se}$ ratios recorded from any magmatic sulfide deposit (see review by Queffurus and Barnes 2015).

The $\mathrm{S} / \mathrm{Se}$ ratios of the sulfides hosted by oxides are compared with those of sulfides from the same sample that are hosted outside of oxides (Fig. 6). This illustrates that $\mathrm{S} / \mathrm{Se}$ ratios of oxide-hosted inclusions are not systematically different from those hosted in other phases or at grain 


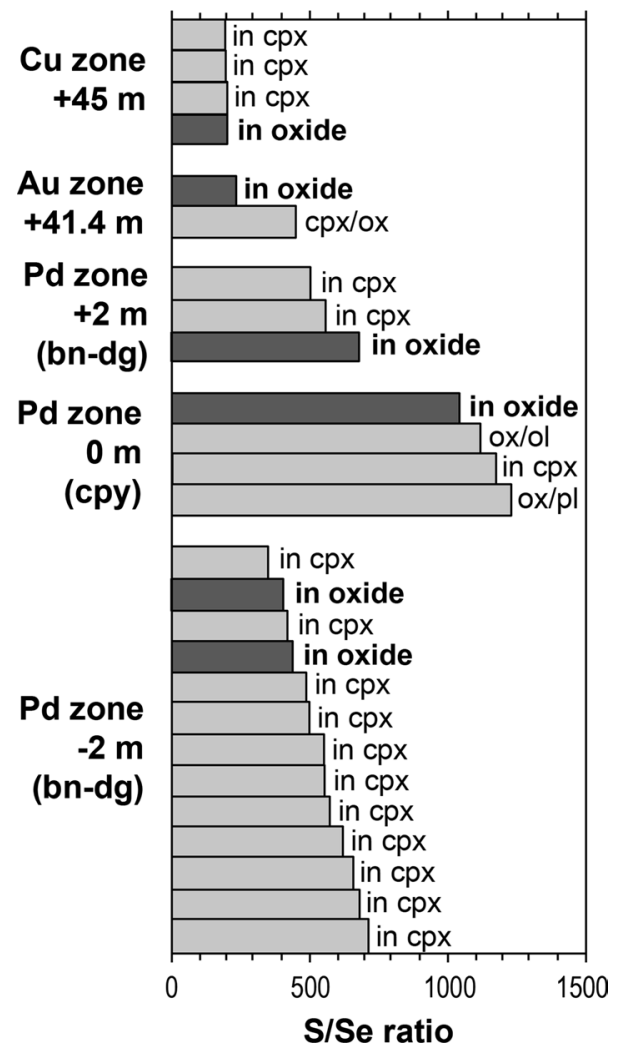

Fig. $6 \mathrm{~S} / \mathrm{Se}$ ratios of oxide-hosted inclusions compared to other textural associations in the same sample

boundaries. Godel et al. (2014) demonstrated that sulfides hosted within oxides contained consistently lower Pd tenors than those on the outside of oxides. This relationship does not appear to extend to Se, however, with comparable Se concentrations (and thus $\mathrm{S} / \mathrm{Se}$ ratios) in sulfide blebs within any one sample, irrespective of the textural association.

\section{Other semimetal concentrations}

The laser ablation TRA spectra show that Te can be distributed inconsistently (Fig. 3). In the Subzone, Pd and Intermediate zones, Te is present in solid solution in very low concentrations (typically a few ppm; Table 2), but can occasionally be seen as small peaks in the TRA spectra indicating its presence in PGM (Fig. $3 \mathrm{~h}-\mathrm{j}$ ) as telluride minerals such as keithconnite and merenskyite (Table 1; Nielsen et al. 2005, 2015). In the $\mathrm{Au}$ and $\mathrm{Cu}$ zones, $\mathrm{Te}$ is present not only in PGM but also in much higher concentration in solid solution in the sulfides (Fig. 3b-e; Table 2) in concentrations of several tens to a few hundred ppm, though concentrations above around $150 \mathrm{ppm}$ may be indicative of large PGM (see Online Resource 1; Figs. 4e, 5b). The highest concentrations of $\mathrm{Te}$ are, like $\mathrm{Se}$, at the base of the $\mathrm{Cu}$ zone, but above the main Au peak (Fig. 4e, j) and the positive correlation between Te and Se shown in Fig. 5b indicates that in these sulfides, both elements are present in roughly proportional amounts. The Upper Zone sample contains less than $1 \mathrm{ppm}$ Te in solid solution in the sulfides (Table 2; Fig. 5b).

Bismuth was detected in most of the droplets analyzed at concentrations of up to around $20 \mathrm{ppm}$, though most contained less than $1 \mathrm{ppm} \mathrm{Bi}$ (Table 2; Fig. 5c). There is no relationship whatsoever between $\mathrm{Se}$ and $\mathrm{Bi}$ in any of the Platinova Reef zones (Fig. 5c). There is no correlation between $\mathrm{Te}$ and $\mathrm{Bi}$ (Fig. 5d). Both $\mathrm{Te}$ and Bi are known to be relatively incompatible in sulfide minerals (e.g., Helmy et al. 2010), and so high values likely represent the ablation of bismuthides and tellurides. Arsenic and $\mathrm{Sb}$ were not detected in the majority of sulfides analyzed (Online Resource 1), except in rare cases where PGM containing trace $\mathrm{Sb}$ or As were ablated (e.g., Fig. 3j).

\section{Discussion}

This work represents the first in situ, LA-ICP-MS study of the sulfide droplets in the Platinova Reef. It has revealed a number of important new geochemical characteristics of the sulfide mineralization to add to previous work and the recognition of extremely high precious metal tenors:

1. The LA-determined Pd tenors of the sulfides are extremely high and are in the same range as those calculated from bulk rock (Holwell and Keays 2014) and 3D volume analysis (Godel et al. (2014), varying from $100 \mathrm{~s}$ of ppm to $10 \mathrm{~s}$ of $\%$.

2. The sulfides contain extremely high concentration of Se in solid solution in addition to the high precious metal tenors they are known to have. There is a significant peak in their Se contents at the base of the $\mathrm{Cu}$ zone, but above the main Au peak;

3. The sulfides have the lowest $\mathrm{S} / \mathrm{Se}$ ratios recorded in any known magmatic sulfide deposit;

4. S/Se ratio does not differ systematically depending on textural context of the sulfide bleb.

5. Tellurium is also highly enriched and is present both as a discrete PGM as well as in solid solution in the sulfides and also shows a peak at the base of the $\mathrm{Cu}$ zone, immediately above the Au peak.

6. In detail, the peak metal offsets up through the reef are $\mathrm{Pt}+\mathrm{Pd}>\mathrm{Au}>\mathrm{Te}>\mathrm{Se}>\mathrm{Cu}$.

7. There is a range of sulfide textures that appear to be the product of syn- and post-magmatic processes.

These points are discussed below in terms of the processes that may have operated to produce such features, with particular reference to our new $\mathrm{Se}$ and $\mathrm{S} / \mathrm{Se}$ ratio data. In doing so, we are able to add to the current models for the 
genesis of the Platinova Reef and assess the implications for other similar Skaergaard-type deposits.

\section{Size and timing of entrapment of sulfide microdroplets in the Platinova Reef}

Textural observations of the petrography of samples from the Triple Group indicates that plagioclase occurs as lath-like plagioclase cumulus crystals (e.g., Godel et al. 2014) with clinopyroxene and $\mathrm{Fe}-\mathrm{Ti}$ oxides making up the remainder of the rock. We concur with the conclusions of Godel et al. (2014) that sulfide droplets in the precious metal-enriched zones formed as cumulus phases and that they were then trapped more or less in situ as liquid droplets by crystallizing clinopyroxene and $\mathrm{Fe}-\mathrm{Ti}$ oxides. The textures observed within this population of sulfide blebs (Fig. 2h, k) are interesting in that they show feathered boundaries focussed in a single direction that are not related to the encroachment of alteration silicates (c.f. Fig. 2f). We propose that the texture seen in Fig. 2k is the result of entrapment of a rounded sulfide droplet in clinopyroxene and that some of that sulfide liquid was squeezed along cleavage planes in the clinopyroxene which had crystallized at a temperature when the sulfide was still liquid.

Experimental work by Chung and Mungall (2009) showed that microdroplets of dense sulfide liquid have the ability to settle through very narrow pore channels, with the possibility of coalescing at 'dead ends.' There is no evidence of coalescence of droplets in the Platinova Reef, so if they did migrate through pore space, the speed of migration was equal to, or less than, the advancement of the crystallization front. As such, this puts a constraint on the settling velocity of the smallest droplets as being similar to or slower than the crystallization rate and we do not envisage that the tiny sulfide droplets below the $\mathrm{Cu}$ zone had the ability to significantly settle or migrate downwards before being trapped.

These interpretations have a single and extremely important implication. The sulfide microdroplets almost certainly did not have the ability to interact with a large amount of magma, which raises a problem in attempting to explain their extremely high metal contents which would normally require equilibration of the sulfides with a large volume of silicate magma (high $\mathrm{R}$ factor). However, the inference from the $\mathrm{Cu} / \mathrm{Pd}$ data (Fig. 1e) is that the sulfides in the $\mathrm{Cu}$ zone formed from magma depleted of its PGE. Thus, there is an apparent paradox of sulfides that apparently did not interact with much magma, containing very high PGE tenors (below the $\mathrm{Cu}$ zone), but evidence of large-scale depletion of the magma above. Explanations for this will be covered below.

In the $\mathrm{Cu}$ zone, sulfide droplets are more abundant, larger and are found as inclusions in plagioclase as well as clinopyroxene and $\mathrm{Fe}-\mathrm{Ti}$ oxides. We interpret this as evidence that these droplets separated from magma largely devoid of crystals and were able to settle downwards into the underlying crystal mush to a greater extent than those below. They were then trapped in all crystallizing phases as they approached the crystal-magma interface, as suggested by Holwell and Keays (2014). This population of sulfides arrived earlier at the margins of the bowl-shaped chamber floor than they did in its center; hence, the stratigraphic separation between the main Pd peak and the $\mathrm{Cu}$ zone is less at the margins of the intrusion than at its center.

\section{Precious and semimetal characteristics of the sulfides}

Despite the 'nuggety' occurrence of elements like the PGE, Au and Te that may be exacerbated by polishing, our approach of incorporating any PGM into the determination of bulk sulfide droplet compositions appears to be reliable if the mean values are considered. Mean Pd and Au tenors (Table 2) are of the same order of magnitude and thus consistent with that calculated by Holwell and Keays (2014) and Godel et al. (2014), despite a wide range (e.g., Fig. 4a). The determination of elements in solid solution, such as $\mathrm{Se}$ is, however, more precise (c.f. Fig. 4a, c).

Overall, the sulfides of the Platinova Reef are remarkable in several respects. They have the highest PGE tenors of any magmatic sulfides, with only the J-M Reef in Stillwater intrusion containing sulfides with PGE tenors of over 5000 ppm (Barnes and Naldrett 1985; Godel and Barnes 2008). Furthermore, they have the highest Se concentrations (400-1200 ppm) ever recorded in magmatic sulfide ores (c.f. Queffurus and Barnes 2015). For comparison, Se is generally present in sulfide minerals in the range of tens of ppm, up to around $250 \mathrm{ppm}$ in some sulfide minerals (e.g., Dare et al. 2010; 2014; Piña et al. 2013, Prichard et al. 2013; Smith et al. 2014) and up to 455 ppm in sulfides of the Lac des Isles Complex (Djon and Barnes 2012). The S/Se ratios of the Platinova Reef (mostly 190800 ) are lower than any other magmatic sulfide deposit currently recorded (see review by Queffurus and Barnes 2015; Fig. 7). The only other deposit with $\mathrm{S} / \mathrm{Se}$ ratios as low the Platinova Reef is the Platreef (Fig. 7), where McDonald et al. (2012) show sulfide melt inclusions in chromite can have extremely high PGE tenors, and low S/Se ratios that they interpret to be a result of dissolution upgrading (c.f. Kerr and Leitch 2005).

The Te contents of magmatic sulfides are generally in the range of a few ppm (e.g., Dare et al. 2010; 2014; Djon and Barnes 2012; Piña et al. 2013, Prichard et al. 2013; Smith et al. 2014). Our data show that around the Au zone, Te concentrations are in the tens to a few hundred ppm (Table 2; Fig. 4e, j), and thus, the sulfides are anomalously enriched in Te as well as in Se, with the main Te peak 


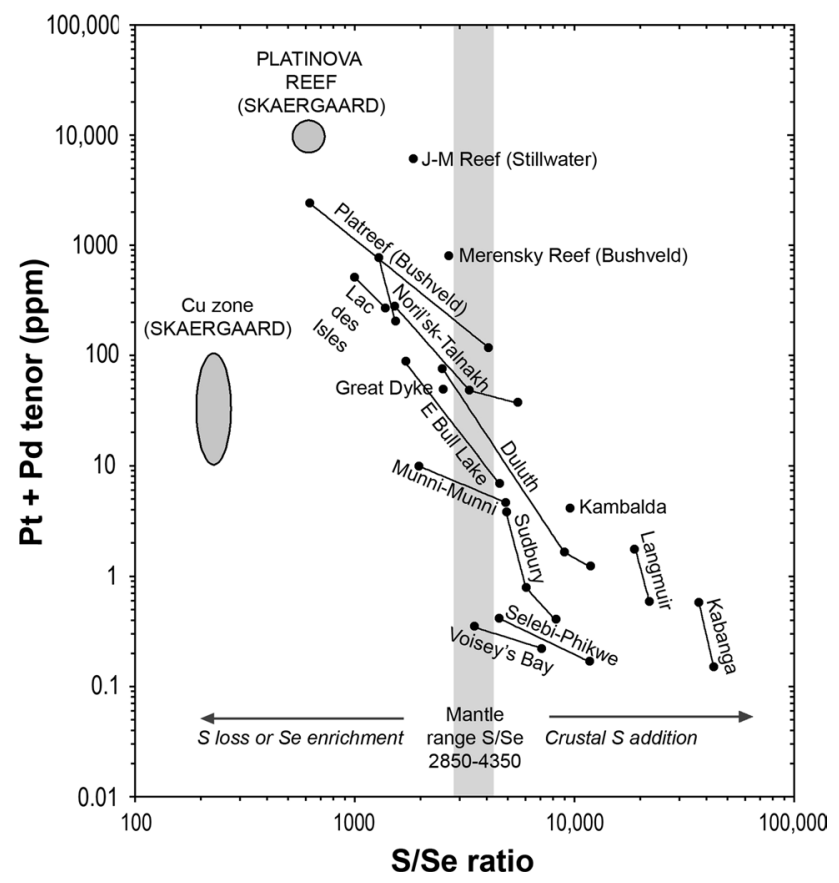

Fig. 7 Range of $\mathrm{S} / \mathrm{Se}$ ratio versus $\mathrm{Pt}+\mathrm{Pd}$ tenor for the Platinova Reef sulfides in comparison with a selection of global magmatic sulfide deposits from Queffurus and Barnes (2015). Platreef data from McDonald et al. (2012). Mantle range is that of Eckstrand and Hulbert (1987)

located just above the main Au peak (Fig. 4e, j). The behavior of $\mathrm{Te}, \mathrm{Bi}, \mathrm{As}$ and $\mathrm{Sb}$ contrasts with that of $\mathrm{Se}$ which remains in solid solution in sulfide, by generally fractionating into immiscible telluride/bismuthide/arsenide and possibly antimonide melts on cooling and crystallization of a sulfide liquid (Helmy et al. 2010, 2013a, b; Holwell and McDonald 2010; Prichard et al. 2013). Furthermore, these melts sequester precious metals more effectively than sulfide melt (Helmy et al. 2010). Although this appears to include a significant amount of $\mathrm{Te}$ in solid solution in sulfide, the high concentrations of $\mathrm{Te}$ at the base of the $\mathrm{Cu}$ zone may also represent the presence of some immiscible telluride melts associated with the sulfides in this zone (e.g., Helmy et al. 2010, 2013a, b); though it is worth noting the dominant mineralogy of the PGE and Au remain as alloys.

While Te and Se are highly enriched, other semimetals are not. Bismuth is present in amounts similar to other magmatic sulfide deposits cited above and therefore is not anomalously enriched and does not show any relationship with Se (Fig. 5c), although it is present with Te in some bismuthotelluride minerals (Figs. 3c, j, 5d). There is almost no As and Sb in the Platinova Reef sulfides, which is likely to reflect parental magma composition (Table 2; Online Resource 1). These elements are often added to magmas by assimilation of crustal rocks (e.g., Hutchinson and Kinnaird
2005; Hutchinson and McDonald 2008) and the paucity of these elements in the Platinova Reef is consistent with the absence of crustal contamination in the Skaergaard magma (McBirney and Creaser 2003). Alternatively, or additionally, the lack of As may be due to it being fractionated with Pt further down the sequence, prior to the main mineralization event. Platinum-arsenides are known to precipitate directly from the magma (e.g., Coghill and Wilson 1993; Ohnenstetter et al. 1999), and this may provide a mechanism to remove both Pt and As during fractional crystallization in the Lower and Middle zones.

Silver is apparently present both in solid solution and as nuggets of Ag-bearing minerals, and so the large variation in $\mathrm{Ag}$ content (Fig. 4b) is, in part, due to the presence of $\mathrm{Ag}$ in both deportments (e.g., Fig. 3e). However, there is a significant dip in the Ag content of the sulfides in the Au zone (Fig. 5a), which is the opposite of the trend seen for Te and Se (Fig. 4). This is most likely due to the presence of significant amounts of $\mathrm{Ag}$ present as minerals in the Au zone that were polished away (e.g., electrum, Table 1). In one sample ( $+40.6 \mathrm{~m}$; Table 2), the high Ag contents correlate with a high $\mathrm{Au}$ content of a $\mathrm{Au}-\mathrm{Ag}-\mathrm{Pd}$ phase. Nielsen et al. (2015) record native $\mathrm{Ag}$, acanthite $\left(\mathrm{Ag}_{2} \mathrm{~S}\right), \mathrm{Pd}-\mathrm{Ag}$ tellurides and $\mathrm{Pd}-\mathrm{Ag}$ sulfides from the Au zone, though we cannot discount that $\mathrm{Ag}$ is actually relatively low in the sulfide assemblage in this zone.

\section{Implications for models for the Platinova Reef}

Figure 7 shows how the Platinova Reef sulfides compare to other magmatic sulfide deposits in terms of S/Se ratio and PGE tenor. Interestingly, the sulfides of the Platinova Reef plot along the same general trend of increasing PGE tenor with decreasing S/Se ratio that Queffurus and Barnes (2015) show for all other magmatic sulfide deposits (Fig. 7). Thus, the Platinova Reef sulfides may be considered to be an extreme end member for high tenor sulfides, and the process that enriched them in PGE may also be responsible for the low S/Se ratios, by way of also enriching them in Se.

The very clear relationship between the $\mathrm{Cu} / \mathrm{Pd}$ ratios and $\mathrm{Pd}$ contents of the rocks in the $\mathrm{Cu}$ zone indicate formation of sulfides from magma that was PGE depleted (Fig. 1e). In complete contrast, the sulfides below the $\mathrm{Cu}$ zone are extremely high tenor and contain much of the bulk of the Skaergaard precious metal budget. Therefore, the process(es) responsible for the formation of the Platinova Reef stripped much of the Au and PGE out of the magma column lying above the Reef (Holwell and Keays 2014; Nielsen et al. 2015; Keays and Tegner 2015). Thus, there needs to be a mechanism by which the majority of the PGE within the Skaergaard magma can be concentrated into a zone of up to a few tens of meters, containing very tiny 
sulfides that most likely formed in situ, but also one that can account for Se and Te enrichment in the lower portions of the more sulfide-rich $\mathrm{Cu}$ zone as well.

Here we focus on our new and very well-constrained Se and $\mathrm{S} / \mathrm{Se}$ data to assess the processes responsible for the development of the Platinova Reef. In particular, we look at the magnitude of enrichment in the sulfides, and the reasons for the extremely low S/Se ratios. Firstly, it is important to know whether the observed Se concentrations and $\mathrm{S} / \mathrm{Se}$ ratios are simply inherited from the bulk Skaergaard magma composition. Keays and Tegner (2015) record an initial Se value for the Skaergaard magma of $85 \mathrm{ppb}$, from a sample of the intrusion's chilled margin; they obtained an initial value of $95 \mathrm{ppb}$ Se from modeling the distribution of Se throughout the entire Skaergaard stratigraphy. This is not anomalously high for basaltic rocks; by comparison, MORB glasses contain around 150-300 ppb Se (Peach et al. 1990; Jenner et al. 2010), and thus, we do not consider the Skaergaard magma to be particularly Se enriched to begin with. Therefore, the reason for the extreme enrichment of Se (and other elements) in sulfides must lie in the effectiveness of element enrichment in the processes responsible for, or prior to, sulfide formation.

Similarly, the low S/Se ratios may have been a result of an initially low S/Se ratio in the Skaergaard magma. Keays and Tegner (2015) report a S/Se ratio of the parental Skaergaard magma of 1180, which is well below the chondritic range of $2560 \pm 150$ (Dreibus et al. 1995) and the mantle range of 2850-4350 (Eckstrand and Hulbert 1987). Although the low S/Se ratio of the initial magma may have been one factor, some other process or processes must have been responsible for the low $\mathrm{S} / \mathrm{Se}$ contents of the sulfides in the Platinova Reef and especially those at the base of the $\mathrm{Cu}$ zone. So, although the Skaergaard magma was not enriched in $\mathrm{Se}$, it does appear that it was depleted in S, by around an order of magnitude to that expected of $\mathrm{FeO}$-rich magma, prior to emplacement, or during crystallization. The reasons for this are not clear at present and are beyond the scope of this paper.

\section{Evidence for enrichment of a boundary layer}

In many magmatic sulfide systems, it is possible to model the enrichment of chalcophile elements such as Se into a magmatic sulfide that interacts using the simple $\mathrm{R}$ factor equation from Campbell and Naldrett (1979):

$Y_{i}=\left[D_{i} * Y_{o i} *(R+1)\right] /\left(R+D_{i}\right)$

where $Y_{i}$ is the concentration of metal in the sulfide, $D_{i}$ is the distribution coefficient between sulfide liquid and silicate magma of the metal, $Y_{o i}$ is the original concentration of the metal in the magma, and $R$ is the ratio of the volume of silicate melt to that of the sulfide liquid. However, this requires equilibration of the sulfides with large amounts of silicate liquid, which is seemingly untenable for the Platinova Reef, where tiny sulfides have formed and been trapped in situ.

To illustrate this, if one takes an initial Se content in the Skaergaard magma of $85 \mathrm{ppb}$ and allow for Rayleigh fractionation, the $\mathrm{Se}$ in the residual magma at the time of Triple Group formation would be around $341 \mathrm{ppb}$ (Keays and Tegner 2015). Using a $D_{\text {sul/sil }}$ value of 1388 for Se (Brenan 2015), it is not possible to produce a sulfide with anything more than $473 \mathrm{ppm}$ Se from an initial magma composition of $341 \mathrm{ppb}$ (using R factors in the millions); therefore, the observed concentrations cannot have been attained by the simple relationship given in Eq. (1). In other words, simple $\mathrm{R}$ factor models do not work for Skaergaard. Nevertheless, the PGE, Au and Se tenors of the sulfides are extremely high, and thus, the major mechanism of precious (and semi) metal enrichment must be different to that proposed for more conventional $\mathrm{Ni}-\mathrm{Cu}-\mathrm{PGE}$ sulfide deposits as per Campbell and Naldrett (1979); a view also held by Nielsen et al. (2015).

Given that the sulfides in the Subzone, Pd zone and Intermediate zone formed more or less in situ, the very high metal tenors indicate an apparent mass balance problem. If we take the Pd grade for the Subzone to be $0.47 \mathrm{ppm}$ over $8 \mathrm{~m}, 1.7 \mathrm{ppm}$ over $4 \mathrm{~m}$ in the Pd zone and $0.54 \mathrm{ppm}$ over $36 \mathrm{~m}$ in the Intermediate zone (data from drill hole PRL1047; Holwell and Keays 2014), this gives an average bulk grade over this $48-\mathrm{m}$ section of $0.5 \mathrm{ppm} \mathrm{Pd}$ (equivalent to $\sim 1000 \mathrm{~m}$ of stratigraphy at $10 \mathrm{ppb} \mathrm{Pd}$ ). In order to produce sulfides that form in situ that contain these grades, the magma from which the Platinova Reef sulfides segregated must have had anomalously high chalcophile elements contents. As such, the presence of an enriched boundary layer at the base of the chamber is an attractive explanation, though the generation of this may have occurred in a number of ways.

Continued crystallization of the magma chamber could potentially enrich a boundary layer in incompatible elements (such as PGE, $\mathrm{Au}, \mathrm{Se}$ and $\mathrm{Te}$ ) at the crystal-magma interface in the interstitial melt, and as adcumulates are formed, this will migrate upwards to the top of the crystal pile (e.g., Morse 1986). If it stayed there, it could form an enriched layer at the bottom of the chamber. In such a case, the first sulfides to form would have the ability to become highly enriched due them separating into a super-concentrated layer, though may become trapped by the crystal mush forming around them. The upward metal variations would then be produced by relative $D_{\text {sul/sil }}$ values. In the rest of the chamber, sulfides would have the chance to grow, but would be of lower tenors, and start to settle. When these sulfides arrived at the floor, it would produce a transition from tiny, high tenor sulfides to larger, low tenor sulfides. 
Enrichment of a boundary layer in this manner may well be the major mechanism responsible for the mineralization styles seen at Rincon del Tigre or Stella, with the formation of massive magnetite layers. However, Morse (1986) points out that in the case of mafic magmas, the residual melt will be less dense than the magma and hence will not form a boundary layer that is enriched in the incompatibles (e.g., $\mathrm{Pd})$. This is especially so in the case of the Skaergaard magma, and so we suggest an alternative explanation for the extreme enrichment.

However, for the ultra-high tenors at Skaergaard such a process may still not be enough and Keays and Tenger (2015) show that PGE-rich cumulus sulfides started to form in this boundary layer in response to magnetite fractionation some $300 \mathrm{~m}$ below the Platinova Reef, but not in significant amounts. Both Holwell and Keays (2014) and Nielsen et al. (2015) invoke later 'downer' mechanisms that concentrate the bulk of the precious metals into an enriched layer at the base of the chamber at the time of the Triple Group formation to explain the extreme enrichment. Both models involve the well-documented presence of immiscible Fe-rich silicate melts that were present during the formation of the Triple Group formation (Jakobsen et al. 2005; Veksler 2009; Jakobsen et al. 2011; Holness et al. 2011). As the Platinova Reef sulfides formed in this zone, they will have been subject to interaction with such liquids, and it is likely they played some role in the development of the characteristics of the Platinova Reef. Holwell and Keays (2014) suggest that sulfides formed along the roof and margin sequestered the precious metals and that these sulfides totally dissolved in the immiscible Fe-rich melts present at the floor to produce an enriched basal layer. In the model of Nielsen et al. (2015), it is the Fe-rich silicate melts that dissolve and transport the precious metals to the floor. In either case, the extreme tenors and the high apparent $\mathrm{R}$ factors at Skaergaard are fundamentally linked to a boundary layer that had anomalously high chalcophile metal contents that were much higher than those calculated by Rayleigh fractionation alone.

Our new data imply that if this was the case, the sulfides that formed the base of the $\mathrm{Cu}$ zone interacted with a significantly Se-enriched magma; however, this zone was not particularly enriched in $P G E$, thus possibly indicating some variable stratification of PGE-, Se- and Te-enriched zones in any boundary layer, or at least a thicker zone of Se enrichment than PGE enrichment. In the model of Holwell and Keays (2014), sulfides sequestered the majority of the precious metals and dissolved as they approached the floor. The first elements to be resorbed by the magma would be Fe and $\mathrm{S}$, which have low partition coefficients. These would be followed by Se which would start to dissolve back into the magma earlier than the PGE due to its lower $D_{\text {sul/sil }}$ value (1388 for Se; Brenan 2015; compared with
$>536,000$ for Pd; Mungall and Brenan 2014), and thus, the zone of enrichment in Se would be greater than that proposed for the PGE enrichment. Therefore, the highest Se enrichment at the base of the $\mathrm{Cu}$ zone could be explained by these sulfides being the earliest droplets of subsequent sulfide that settled through and encountered a Se-enriched zone and were therefore able to become extremely enriched in Se as they sank (thus attaining a higher $\mathrm{R}$ factor than the sulfides below that formed in situ as discussed above). The subsequent decrease in Se values with height up through the $\mathrm{Cu}$ zone is a function of Se being depleted in the magma by being taken up by the settling sulfides, such that with height, there was less Se in the magma for the sulfides to collect. The same is likely to be the case for Te, which shows a similar peak at the base of the $\mathrm{Cu}$ zone.

The exceedingly low $\mathrm{S} / \mathrm{Se}$ ratios in the $\mathrm{Cu}$ zone, and especially their upward increase (Fig. 4c), provide further insight. Queffurus and Barnes (2015) show that there are number of syn- and post-magmatic processes that can affect $\mathrm{S} / \mathrm{Se}$ ratios, many of which will cause a decrease in $\mathrm{S} / \mathrm{Se}$, and as such, S/Se ratios can be used to trace a number of ore-forming and modifying processes. Of those which can cause a lowering of the initial $\mathrm{S} / \mathrm{Se}$ ratios include: increases in $\mathrm{R}$ factor (or an analogous process such as sulfide dissolution), metamorphism, hydrothermal alteration and serpentinization. For the Platinova Reef, we can discount metamorphism and serpentinization (which are absent at Skaergaard); however, hydrothermal activity may be a possibility, with $\mathrm{S}$ removed by migrating fluids. However, as shown in Fig. 2, many of our analyses are of sulfides that have little to no evidence of alteration, and the $\mathrm{S} / \mathrm{Se}$ ratios remain consistently low throughout the dataset, irrespective of the degree of alteration. Therefore, we interpret the ratios result from magmatic processes.

Due to the higher $D_{\text {sul/sil }}$ value of Se compared to S, variations in $\mathrm{R}$ factor should effectively control the $\mathrm{S} / \mathrm{Se}$ ratio in sulfides in the same way it controls PGE tenor (Queffurus and Barnes 2015). In other words, as $\mathrm{R}$ factor increases, the PGE and Se become enriched in the sulfide liquid due to their high $D_{\text {sul/sil }}$ values. Thus, in very high $\mathrm{R}$ factor systems, PGE and Se tenors will be high, and consequently, S/ Se ratios will be low. Although we have argued that $\mathrm{R}$ factors may have been very low below the $\mathrm{Cu}$ zone, there is likely to be an increase in $\mathrm{R}$ factor above the $\mathrm{Au}$ zone as the larger sulfides in the $\mathrm{Cu}$ zone had the ability to grow and interact with a greater volume of magma, as discussed above. Thus, the increase in Se (and decrease in $\mathrm{S} / \mathrm{Se}$ ) at the base of the $\mathrm{Cu}$ zone could reflect an increase in the $\mathrm{R}$ factor. However, if this is the case, this process operated for $\mathrm{Se}$ in the $\mathrm{Cu}$ zone, but not the precious metals. This may indicate the presence of a much thicker zone of Se enrichment in the boundary/basal layer of magma compared with the PGE. 
Magmatic processes responsible for producing very high tenors

Even with the presence of an enriched boundary layer, the tenors of the Platinova Reef sulfides are so high, a number of other mechanism are likely to be responsible for the both the ultra-high tenors and the metal offsets. Sulfide dissolution (Kerr and Leitch 2005) produces the same effect, with high $D_{\text {sul/sil }}$ elements such as Se and PGE retained preferentially in a dissolving sulfide. Therefore, sulfide dissolution (as suggested by Godel et al. 2014) could reduce the $\mathrm{S} / \mathrm{Se}$ ratio along with increasing the PGE tenor of a sulfide droplet. This mechanism alone cannot be the cause of the exceedingly low $\mathrm{S} / \mathrm{Se}$ ratios at the base of the $\mathrm{Cu}$ zone as they have relatively low PGE tenors. However, Godel et al. (2014) demonstrate that Pd tenors in the Pd zone appear to be lower in sulfide blebs included within oxide and interpret that the sulfides present in oxides were protected from dissolution, while those outside partially dissolved. Our data show no systematic variation in S/Se ratio with textural association (Fig. 6), and therefore, the S/Se data do not support preferential dissolution of sulfides outside of oxides. If so, one would expect the oxide-hosted sulfides to have the highest $\mathrm{S} / \mathrm{Se}$ ratios, whereas in fact, they have relatively low $\mathrm{S} / \mathrm{Se}$ ratios in some cases. We do not dispute the observations of Godel et al. (2014) and therefore suggest there may be an alternative explanation for the disparity between apparent Pd tenors and S/Se ratios on a bleb-bybleb scale. This would require a slightly different concentration mechanism for the PGE than for Se.

One possibility would be whether the Pd-rich phases nucleated separately in the magma as PGM phases (e.g., the 'clusters' model of Tredoux et al. 1995; and subsequent work by Ballhaus and Sylvester 2000; Helmy et al. 2013a, b). If sulfide liquid droplets nucleated on such phases, then on the individual bleb scale, the droplets may have been able to grow to different sizes. This would produce sulfide-PGM aggregates of different Pd tenors, but the S/ Se ratio of the sulfide should be broadly similar, irrespective of the size. Karup-Møller et al. (2008) show experimentally that $\mathrm{PdCu}$ can form from a $\mathrm{Pd}$-rich $\mathrm{Cu}$ sulfide liquid, though this does not necessarily mean that the Pd was not collected by the sulfide as a preformed phase. Alternatively, mechanical splitting of the sulfide-PGM droplets during crystallization of the surrounding minerals may have necked some sulfide liquid and produced more than one microdroplet from a single parent droplet. In this case, the PGM may be preferentially retained by one of the new droplets, resulting in variable Pd tenors, but keeping the S/ Se ratio the same.

Mungall (2002) demonstrated that small sulfide droplets formed from sulfide saturated silicate melts that do not coalesce will preserve metal compositions controlled by kinetic effects; this situation is directly applicable to the Platinova Reef. The concentration of any element in the sulfide is a function not only of how chalcophile that element is (the equilibrium metal partitioning: $D_{\text {sul/sil }}$ ) but also the diffusivities of the most chalcophile elements. Metals that diffuse into the droplet faster than $\mathrm{Fe}^{2+}$ and $\mathrm{S}^{2-}$ cause the concentrations of those metals to rise faster than they can be diluted by the growing droplet, thus producing a high apparent $\mathrm{R}$ factor in the earliest microdroplets. As such, sulfides that demonstrate high apparent $\mathrm{R}$ factors can result from the removal of small amounts of sulfide at small degrees of sulfide saturation. Modeling of this effect by Mungall (2002) showed that the offset metal profiles in the Munni Munni Intrusion, Australia, could be accounted for by fractional segregation of kinetically fractionated sulfide droplets. Therefore, this mechanism could explain both the offset nature of the metal profiles and the very high apparent $\mathrm{R}$ factor of the PGE-enriched sulfides in deposits such as the Platinova Reef. While this apparently explains several of the generic features well, in bulk terms, the in situ crystallization of sulfides would still need a starting magma composition in the region of $0.25-0.5 \mathrm{ppm} \mathrm{Pd}$, as discussed above. As such, even if the kinetic diffusion model is partly responsible for the metal offsets and concentration, there appears to be a requirement for further enrichment by at least one other process.

\section{The role of syn- or post-magmatic fluids}

Our observations of the textures of the sulfide droplets are generally in agreement with textures reported in previous mineralogical studies (e.g., Bird et al. 1991; Andersen et al. 1998; Cabri et al. 2005; Nielsen et al. 2005; Godel et al. 2014). Sulfides trapped within oxides and pyroxenes have rounded droplet morphologies or negative crystal shapes consistent with trapping of very small droplets of sulfide liquid (Ohnenstetter et al. 1999). Alteration of the sulfides by secondary, hydrous silicates such as actinolite-tremolite-talc, as is common in many PGE sulfide deposits (e.g., $\mathrm{Li}$ et al. 2004; Hutchinson and Kinnaird 2005; Holwell et al. 2006), is variable in the Platinova Reef (e.g., Fig. 2d, f) and therefore alteration must have caused some $S$ loss. There is very little evidence of any post-entrapment alteration and $\mathrm{S}$ loss in many of our samples, which display consistent S/Se ratios (Fig. 4d). Thus, the Se contents and S/ Se ratios are most likely to reflect primary magmatic processes, rather than post-magmatic hydrothermal ones.

Nielsen et al. (2015) and Rudashevsky et al. (2014) invoke late-stage mobilization of $\mathrm{Au}$ by a volatile-bearing residual of the Fe-rich melt to explain the concentration of $\mathrm{Au}$ in the $\mathrm{Au}$ zone; with late deposition of $\mathrm{Au}$ on grain boundaries in a two-stage paragenesis. Following the 'downer' mechanism whereby enrichment of the boundary 
layer takes place, Nielsen et al. (2015) suggest 'upper' redistribution of $\mathrm{Au}, \mathrm{Te}$ and other elements in a late-stage volatile phase forced up by compaction, following their dissolution from molten sulfide droplets. Dissolution and transport of such elements is a possibility and would explain the association of $\mathrm{Au}$ with other volatile phases. However, dissolution of molten sulfide should enrich the melt in $\mathrm{S}$ over Se (due to their respective $D_{\text {sul/sil }}$ values) and produce a melt with a high $\mathrm{S} / \mathrm{Se}$ ratio that may also be enriched in Au. In such a model, this relatively Se-poor but $\mathrm{Au}$ (and Te)-rich melt would be distributed and deposited at the $\mathrm{Au}$ zone. However, our data show that the $\mathrm{Au}$ and $\mathrm{Cu}$ zone actually preserves the highest $\mathrm{Se}$ contents (and thus lowest $\mathrm{S} / \mathrm{Se}$ ratios). Therefore, we favor a model that involves a combination of magmatic processes, with the respective metal peak offsets being determined in order of $D$ values.

\section{Peak metal offsets and relative $D$ values}

One of the main characteristics of Skaergaard-like deposits is the presence of offsets in PGE, Au and Cu peaks. Our work has now added Te and Se to that, such that the Platinova Reef displays distinct offset peaks in first $\mathrm{Pt}+\mathrm{Pd}$, then $\mathrm{Au}$, closely followed by $\mathrm{Te}$, and then $\mathrm{Se}$, then $\mathrm{Cu}$. While there is generally some uncertainty of the precise partition coefficients of these metals into sulfide (Mungall and Brenan 2014), and some variability determined by such factors as $\mathrm{FeO}$ content in the magma (e.g., Brenan 2015), the generally accepted values are entirely consistent with the observed sequence in the Platinova Reef. The $D_{\text {sul/sil }}$ for $\mathrm{Pd}$ and $\mathrm{Pt}$ are $\sim 500,000$ and 300,000, respectively (Mungall and Brenan 2014). The $D_{\text {sul/sil }}$ for Au is lower and may be as high as 18,600 (Peach et al. 1990), though Brenan and Mungall report values up to 11,200 . Brenan (2015) report $D_{\text {sul/sil }}$ values for Te in the range $1005-10,000$ and Se 200 1920 , but note that Te is always more compatible than Se under any given conditions. As such, the sequence of metal offsets is entirely consistent with magmatic partitioning into sulfide.

\section{Implications for the formation of the Skaergaard-like deposits}

It is clear that the formation of stratiform $\mathrm{Cu}$ sulfide dominant PGE reef in the upper parts of layered intrusions is potentially the product of a number of concurrent high-temperature, largely orthomagmatic processes, but that differ from conventional R factor models. However, the comparable characteristics of many of these deposits imply that some of these processes are likely to be 'essential' and common to all intrusions, with the differences in the detailed geochemistry and mineralogy being related to other 'non-essential' processes, applicable to some. We can summarize that the following processes explain a number of the key features of these deposits:

Essential processes are as follows:

1. Late-stage sulfide saturation: position of the reef in the upper parts of the intrusion, $\mathrm{Cu}$-rich, Ni-poor nature of the sulfides;

2. An enriched boundary layer, possibly formed by dissolution of sulfides and/or the migration of metal-rich Fe-rich melts: ability for metal enrichment despite low $\mathrm{R}$ factors;

3. Magnetite crystallization: trigger for sulfide saturation (though this can be gradual, as at Skaergaard);

4. Kinetic fractionation: enrichment of the first, tiny sulfides in precious metals and the metal offsets; and

5. Differences in Dsul/sil values: metal offsets.

Non-essential processes but advantageous are as follows:

6. Change in $\mathrm{R}$ factor: increase in sulfide volume with concurrent Se and Te peak and reduction in S/Se ratios;

7. Partial dissolution of sulfide: increased metal tenors, reduction in $\mathrm{S} / \mathrm{Se}$;

8. Total dissolution of sulfide: pre-enrichment of a magma package for sulfides to separate into and gain extremely high tenors and extremely low $\mathrm{S} / \mathrm{Se}$ ratios, the Se peak at the base of the $\mathrm{Cu}$ zone;

9. Presence of immiscible Fe-rich silicate melts: allows for dissolution of sulfide in a closed-system magma chamber; and

10. Hydrothermal alteration: $\mathrm{S}$ loss, reduction in $\mathrm{S} / \mathrm{Se}$ ratios and increased metal tenor, possible redistribution of metals.

Figure 8 shows a generalized model for the process of extreme enrichment of PGE and semimetals in a closedsystem magma chamber based on a combination of the processes and models developed for the Skaergaard Intrusion, but which also may be applicable to varying degrees for other intrusions. Initial sulfide saturation is triggered by prolonged fractional crystallization and compounded by magnetite crystallization. In the case of the Platinova Reef, the dissolution of a conventionally metalenriched sulfide liquid by interaction with immiscible Fe-rich silicate melts formed a small, enriched package of silicate magma (Fig. 8a) which became primed for a subsequent interaction with sulfide liquid during a second stage of sulfide saturation. First-stage dissolution is seen as 'essential' for the Platinova Reef in order to generate the extreme metal enrichment as discussed above, 
a

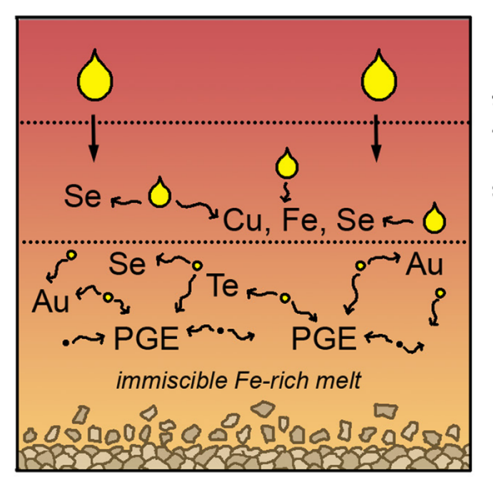

b

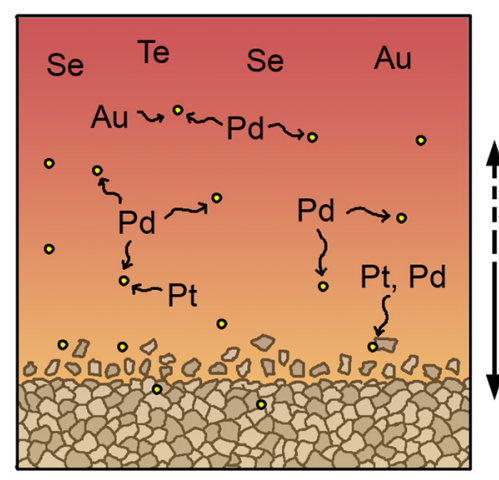

C

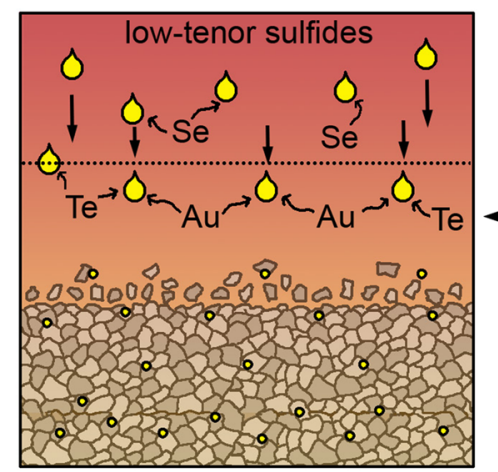

$\leftarrow$ Transition to higher volume $\oint_{\begin{array}{l}P d+P t \\ \text { in sulfide }\end{array}}$

Pd+Pt-rich sulfides

\section{zone of PGE, Au, and Te enrichment in boundary layer \\ zone of $\mathrm{Se}$ enrichment in boundary layer}

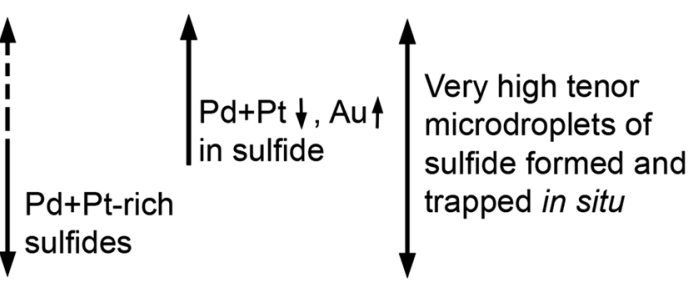

\author{
Early stage sulfide \\ sequesters chalcophile \\ elements from the \\ magma and is \\ dissolved at the base \\ of the chamber, \\ releasing the most \\ chalcophile elements \\ at the lowest level
}

\section{Further fractionation and sulfide saturation (Skaergaard);}

Onset of sulfide saturation (other intrusions):

Chalcophile elements enriched in sulfide in the order $\mathrm{Pd}+\mathrm{Pt}>\mathrm{Au}$ by diffusive partitioning and $D$ sul/sil values
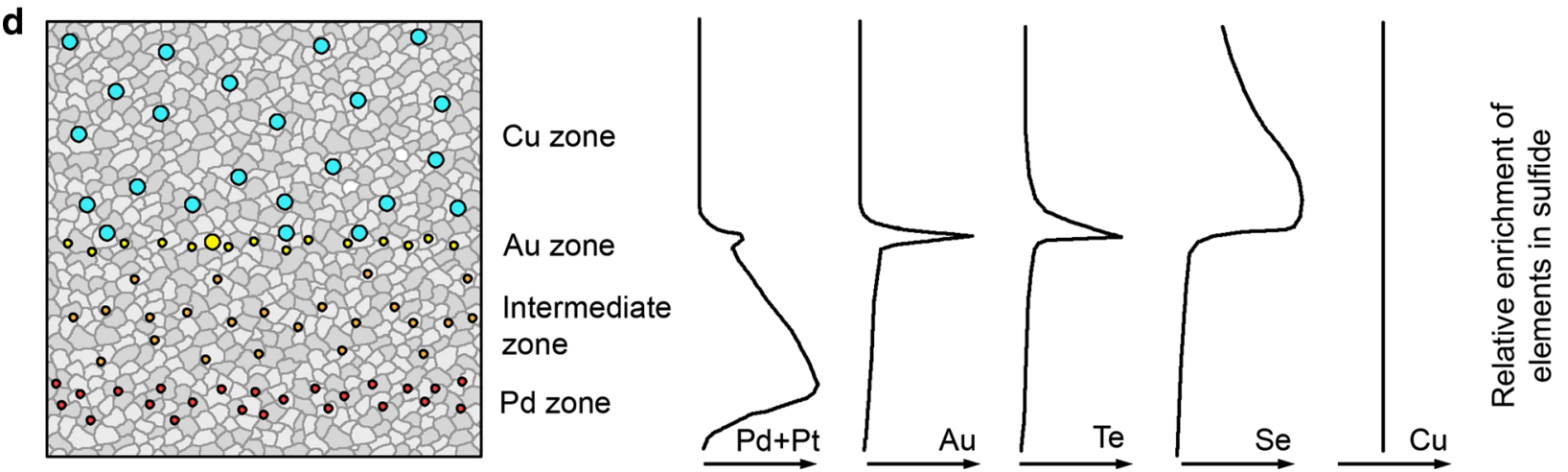

Fig. 8 Schematic model for the extreme enrichment of chalcophile elements in the Platinova Reef (modified after Holwell and Keays 2014). a An initial sulfide liquid sequestered most of the chalcophile elements from the magma before re-dissolving back into a thin zone of magma at the base of the chamber, enriching it in $\mathrm{Se}, \mathrm{Te}, \mathrm{Au}$ and PGE; $\mathbf{b}$ formation of sulfide microdroplets then sequester the chalcophile elements from the enriched magma in sequence according to their relative partition coefficients, with $\mathrm{Pd}+\mathrm{Pt}$ enriched first, with increasing Au upwards; $\mathbf{c}$ the formation of low tenor sulfides from the S-saturated magma above settle to the crystal-magma interface and $\mathrm{Au}$ and then $\mathrm{Te}$ are enriched in the sulfides at the transition, with Se enriched in the first wave of settling sulfides; $\mathbf{d}$ the relative abundances of chalcophile elements in sulfides through the Platinova Reef, illustrating the metal offset pattern 
though may not be necessary in other cases. Microdroplets of sulfide (from either an initial or secondary stage of sulfide saturation) can become highly enriched in chalcophile element through kinetic effects as suggested by Mungall (2002) as well as conventional metal partitioning (Fig. 8b). Thus, the size of the sulfide droplets in such a situation needs only to be small, without the necessity to grow, coalesce and settle through a magma column, and may be trapped in situ as tiny, metal-rich sulfides. As such, the nature of such deposits is unusual in that they may have extremely low volumes of sulfides which host the PGE and thus be extremely difficult to identify in the field. The onset of major sulfide saturation and the formation of larger droplets of sulfides provide a critical transition from high tenor sulfides trapped in situ to larger, lower tenor sulfides that may have settled (Fig. 8c). This marks a change to higher $\mathrm{R}$ factors, but actually lower PGE tenors. The transition is marked by an immediate peak in $\mathrm{Au}$ and very closely followed by $\mathrm{Te}$ and then by a peak Se, such that the metal offsets through the reef profile mirror the effects of chemical and kinetic partitioning $\mathrm{Pt}+\mathrm{Pd}>\mathrm{Au}>\mathrm{Te}>\mathrm{Se}>\mathrm{Cu}$ (Fig. 8d). Late- or post-magmatic $\mathrm{S}$ loss may then upgrade the metal tenors further, but we advocate that the metal offsets and enrichments can be explained entirely by magmatic processes and do not require any fluid mobilization of metals.

In more general terms, because the proposed evolution of the mineralization involves more than one sulfide regime (and associated $\mathrm{R}$ factor), the geochemical signatures present in the rocks are a function of more than one process. Therefore, some features may be amplified or even eradicated from that expected from a single-stage process of sulfide liquid enrichment and settling. In particular, the paucity of $\mathrm{S}$ in these deposits and low $\mathrm{S} / \mathrm{Se}$ ratios are a result of primary magmatic processes that are analogous to an increase in apparent $\mathrm{R}$ factor. Furthermore, low $\mathrm{S}$ contents do not necessarily require post-magmatic hydrothermal S loss, but can be the product of a number of concurrent high-temperature processes as discussed by Keays and Tegner (2015).

This study illustrates that magmatic sulfides are able to acquire extremely high metal and semimetal tenors and exceedingly low $\mathrm{S} / \mathrm{Se}$ ratios in situ without the need to necessarily interact with a large volume of magma, through a number of mechanisms. However, in order to obtain the extreme enrichment of metals and semimetals as is the case of the Platinova Reef, we suggest that pre-enrichment of a basal layer of magma was probably required, in addition to a combination of other processes. As such, while 'Skaergaard-type' deposits have a number of common characteristics, Skaergaard itself may simply be unique (Figs. 7, 8).

\section{Summary}

Laser Ablation-ICP-MS of sulfide droplets from Platinova Reef confirms a significant shift in trace element concentrations of bornite-digenite/chalcocite droplets across the $\mathrm{Au}$ zone. Below the $\mathrm{Au}$ zone, the sulfides are enriched in $\mathrm{Se}, \mathrm{Te}$ and PGE, whereas the transition across the Au zone to higher volumes of sulfide corresponds with a decrease in PGE content, but a significant increase in Te, and especially Se content. The $\mathrm{S} / \mathrm{Se}$ ratios are the lowest recorded in any magmatic sulfide deposit, and mineralogical evidence implies this is not due to any significant post-magmatic hydrothermal $\mathrm{S}$ loss, but is rather a function of magmatic processes. Conventional $\mathrm{R}$ factor models do not apply to tiny sulfides formed in situ, and therefore, the reason for the extreme enrichment of precious and semimetals in sulfides must lie in the effectiveness of element enrichment in the processes responsible for, or prior to, sulfide formation. The most likely process that can produce such highly PGE and Se-enriched sulfides (and subsequently such low $\mathrm{S} / \mathrm{Se}$ ratios) is if the sulfides segregated from a highly chalcophile element enriched package of magma, although other processes, such as kinetic diffusion, may have also occurred alongside this to enhance the high tenors. The Au zone represents a transition zone, below which microdroplets of sulfides that formed and were trapped in situ. Sulfides formed above the Au zone were larger, low tenor sulfides that grew and settled (thus higher $\mathrm{R}$ factor) through an already PGE and Au depleted magma. The basal portions of this downward moving sulfide front sequestered large amounts of excess $\mathrm{Se}$ as it encountered the pre-enriched layer. As such, a characteristic metal offset pattern is observed (controlled by partitioning effects), but is superimposed with a change in sulfide regime (controlled by in situ trapping versus pre-entrapment growth and settling). In this case, the metal peaks follow the sequence $\mathrm{Pt}+\mathrm{Pd}>\mathrm{Au}>\mathrm{Te}>\mathrm{Se}>\mathrm{Cu}$, exactly in order of $\mathrm{D}$ values. This work illustrates that extreme precious and semimetal enrichment in sulfide droplets can occur in closed-system layered intrusions, but that this will characteristically form ore deposits that are so low in sulfide that they do not conform to conventional deposit models for $\mathrm{Cu}-\mathrm{Ni}-\mathrm{PGE}$ sulfides.

Acknowledgments The data used in this study are part of a collaborative project between Platina Resources Limited and the University of Leicester. Platina Resources Ltd and, in particular, Mark Dugmore and Ben Sharp are thanked for allowing access to these samples, and Tom Abraham-James for discussions throughout the past 6 years working on this project. This work was part funded by a NERC SoS Minerals catalyst grant NE/L002191/1 awarded to the University of Leicester and by a NERC SoS Consortium grant NE/M010848/1 'TeaSe: tellurium and selenium cycling and supply' awarded to the University of Leicester and Cardiff University. We would like to thank 
Troels Nielsen for two helpful and extremely detailed reviews and further constructive suggestions by Belinda Godel and Chris Ballhaus, all of which helped to improve the quality and focus of the manuscript. Richard Prasser is thanked for providing some of the images used in Fig. 2.

Open Access This article is distributed under the terms of the Creative Commons Attribution 4.0 International License (http://creativecommons.org/licenses/by/4.0/), which permits unrestricted use, distribution, and reproduction in any medium, provided you give appropriate credit to the original author(s) and the source, provide a link to the Creative Commons license, and indicate if changes were made.

\section{References}

Andersen JCØ (2006) Postmagmatic sulfur loss in the Skaergaard Intrusion: implications for the formation of the Platinova Reef. Lithos 92:198-221

Andersen JCØ, Rasmussen H, Nielsen TFD, Ronsbo JC (1998) The Triple Group and the Platinova gold and palladium reefs in the Skaergaard Intrusion: stratigraphic and petrographic relations. Econ Geol 93:488-509

Ballhaus C, Sylvester PJ (2000) Noble metal enrichment processes in the Merensky Reef, Bushveld Complex. J Petrol 41:545-561

Barnes SJ, Naldrett AJ (1985) Geochemistry of the J-J (Howland) Reef of the stillwater complex, Minneapolis Adit area. I. Sulfide chemistry and sulfide-olivine equilibrium. Econ Geol $80: 627-645$

Barnes SJ, Hoatson DM, Keays RR (1992) Distribution of sulfides and PGE within the mineralized porphyritic Websterite zone of the Munni Munni Complex, Western Australia. Austral J Earth Sci 39:289-302

Barrie CT, MacTavish AD, Walford PC, Chataway R, Middaugh R (2002) Contact-type and magnetitite reef-type $\mathrm{Pd}-\mathrm{Cu}$ mineralization in ferroan olivine gabbros of the Coldwell Complex, Ontario. In: Cabri LJ (ed). Can Inst Min Metall Petrol 54:321-338

Bird DK, Brooks CK, Gannicott RA, Turner PA (1991) A gold-bearing horizon in the Skaergaard Intrusion, east Greenland. Econ Geol 86:1083-1092

Brenan JM (2015) Se-Te fractionation by sulfide-silicate melt partitioning: implications for the composition of mantle-derived magmas and their melting residues. Earth Planet Sci Lett 422:45-57

Brooks CK (1989) Major gold find in Greenland. Terra Nova 1:591-593

Brooks CK, Nielsen TFD (1982) The E Greenland continental margin: a transition between oceanic and continental magmatism. J Geol Soc Lond 139:265-275

Cabri LJ, Beattie M, Rudashevsky NS, Rudashevsky VN (2005) Process mineralogy of $\mathrm{Au}, \mathrm{Pd}$ and $\mathrm{Pt}$ ores from the Skaergaard intrusion, Greenland, using new technology. Miner Eng $18: 887-897$

Campbell IH, Naldrett AJ (1979) The influence of silicate:sulfide ratios on the geochemistry of magmatic sulfides. Econ Geol 74:1503-1506

Chung H-Y, Mungall JE (2009) Physical constraints on the migration of immiscible fluids through partially molten silicates, with special reference to magmatic sulfide ores. Earth Planet Sci Lett 286:14-22

Ciborowski TJR, Kerr AC, McDonald I, Ernst RE, Minifie MJ (2013) The geochemistry and petrogenesis of the Blue Draw Metagabbro. Lithos 174:271-290
Coghill BM, Wilson AH (1993) Platinum-group minerals in the Selukwe Subchamber, Great Dyke, Zimbabwe: implications for PGE collection mechanisms and post-formational redistribution. Mineral Mag 57:613-633

Dare SAS, Barnes S-J, Prichard HM (2010) The distribution of platinum group elements (PGE) and other chalcophile elements among sulfides from the Creighton $\mathrm{Ni}-\mathrm{Cu}-\mathrm{PGE}$ sulfide deposit, Sudbury, Canada, and the origin of palladium in pentlandite. Mineral Depos 45:765-793

Dare SAS, Barnes S-J, Prichard HM, Fisher PC (2014) Mineralogy and geochemistry of $\mathrm{Cu}$-rich ores from the McCreedy East Ni-Cu-PGE deposit (Sudbury, Canada): implications for the behavior of platinum group and chalcophile elements at the end of crystallization of a sulfide liquid. Econ Geol 109:343-366

Djon MLN, Barnes S-J (2012) Changes in sulfides and platinumgroup minerals with the degree of alteration in the Roby, Twilight, and high grade zones of the Lac des Iles Complex, Ontario, Canada. Mineral Depos 47:875-896

Dreibus G, Palme H, Spettek B, Zipfel J, Wanke H (1995) Sulfur and selenium in chondritic meteorites. Meteoritics 30:439-445

Eckstrand OR, Hulbert LJ (1987) Selenium and the source of sulfur in magmatic nickel and platinum deposits (abs). Geol Assoc Can Mineral Assoc Can Prog Abstr 12:40

Godel B, Barnes S-J (2008) Platinum-group elements in sulfide minerals and the whole rocks of the J-M Reef (Stillwater Complex): implication for the formation of the reef. Chem Geol 248:272-294

Godel B, Barnes S-J, Maier WD (2007) Platinum-group elements in sulfide minerals, platinum-group minerals, and whole-rocks of the Merensky Reef (Bushveld Complex South Africa): implications for the formation of the reef. J Petrol 48:1569-1604

Godel B, Rudashevsky NS, Nielsen TFD, Barnes SJ, Rudashevsky VN (2014) New constraints on the origin of the Skaergaard intrusion $\mathrm{Cu}-\mathrm{Pd}-\mathrm{Au}$ mineralization: insights from high-resolution X-ray computed tomography. Lithos 190-191:27-36

Helmy HM, Ballhaus C, Wohlgemuth-Ueberwasser C, Fonseca ROC, Laurenz V (2010) Partitioning of Se, As, Sb, Te and Bi between monosulfide solid solution and sulfide melt-application to magmatic sulfide deposits. Geochim Cosmochim Acta 74:6174-6179

Helmy HM, Ballhaus C, Fonseca ROC, Wirth R, Nagel T, Tredoux M (2013a) Noble metal nanoclusters and nanoparticles precede mineral formation in magmatic sulphide melts. Nat Commum. doi: $10.1038 /$ ncomms 3405

Helmy HM, Ballhaus C, Fonseca ROC, Nagel T (2013b) Fractionation of platinum, palladium, nickel, and copper in sulfide-arsenide systems at magmatic temperature. Contr Miner Petrol 166:1725-1737

Holness MB, Nielsen TFD, Tegner C (2007) Textural maturity of cumulates: a record of chamber filling, liquidus assemblage, cooling rate and large scale convection in mafic larered intrusions. J Petrol 48:141-157

Holness MB, Stripp G, Humphreys MCS, Veksler IV, Nielsen TFD, Tegner C (2011) Silicate liquid immiscibility within the crystal mush: late-stage magmatic microstructures in the Skaergaard intrusion, east Greenland. J Petrol 52:175-222

Holwell DA, Keays RR (2014) The formation of low volume, high tenor magmatic PGE-Au sulphide mineralisation in closed systems: evidence from precious and base metal geochemistry of the Platinova Reef, Skaergaard Intrusion, east Greenland. Econ Geol 109:387-406

Holwell DA, McDonald I (2007) Distribution of platinum-group elements in the Platreef at Overysel, northern Bushveld Complex: a combined PGM and LA-ICP-MS study. Contrib Mineral Petrol 154:171-190 
Holwell DA, McDonald I (2010) A review of the behaviour of platinum group elements within natural magmatic sulfide ore systems. Platin Metals Rev 54:26-36

Holwell DA, McDonald I, Armitage PEB (2006) Platinum group mineral assemblages in the Platreef at the Sandsloot Mine, northern Bushveld Complex, South Africa. Mineral Mag 70:83-101

Holwell DA, McDonald I, Butler IB (2011) Precious metal enrichment in the Platreef, Bushveld Complex, South Africa: evidence from homogenised magmatic sulfide melt inclusions. Contrib Mineral Petrol 161:1011-1026

Hutchinson D, Kinnaird JA (2005) Complex multi-stage genesis for the Ni-Cu-PGE mineralization in the southern region of the Platreef, Bushveld Complex, South Africa. Appl Earth Sci Trans Inst Min Metall 114:B208-B224

Hutchinson D, McDonald I (2008) Laser ablation ICP-MS study of platinum-group elements in sulphides from the Platreef at Turfspruit, Northern Limb of the Bushveld Complex, South Africa. Mineral Depos 43:695-711

Irvine TN, Andersen JCØ, Brooks CK (1998) Included blocks (and blocks within blocks) in the Skaergaard Intrusion: geological relations and the origins of rhythmic modally graded layers. Geol Soc Am Bull 110:1398-1447

Jakobsen JK, Veksler IV, Tegner C, Brooks CK (2005) Immiscible iron- and silica-rich melts in basalt petrogenesis documented in the Skaergaard intrusion. Geology 33:885-888

Jakobsen JK, Veksler IV, Tegner C, Brooks CK (2011) Crystallization of the Skaergaard intrusion from an emulsion of immiscible iron- and silica-rich liquids: evidence from melt inclusions in plagioclase. J Petrol 52:345-373

Jenner FE, O'Neill HSC, Arculus RJ, Mavrogenes JA (2010) The magnetite crisis in the evolution of arc-related magmas and the initial concentration of $\mathrm{Au}, \mathrm{Ag}$ and $\mathrm{Cu}$. J Petrol 51:2445-2464

Karup-Møller S, Makovicky E, Barnes S-J (2008) The metal-rich portions of the phase system $\mathrm{Cu}-\mathrm{Fe}-\mathrm{Pd}-\mathrm{S}$ at $1000^{\circ} \mathrm{C}, 900^{\circ} \mathrm{C}$ and $725^{\circ} \mathrm{C}$ : implications for mineralization in the Skaergaard intrusion. Mineral Mag 72:947-951

Keays RR, Lightfoot PC (2010) Crustal sulfur is required to form magmatic $\mathrm{Ni}-\mathrm{Cu}$ sulfide deposits: evidence from chalcophile element signatures of Siberian and Deccan Trap basalts. Mineral Depos 45:241-257

Keays RR, Tegner C (2015) Magma chamber processes in the formation of the low sulphide magmatic Au-PGE mineralization of the Platinova Reef in the Skaergaard Intrusion, east Greenland. $\mathrm{J}$ Petrol (in press)

Kerr A, Leitch AM (2005) Self-destructive sulfide segregation systems and the formation of high-grade magmatic ore deposits. Econ Geol 100:311-332

Li C, Ripley EM, Maier WD, Gomwe TES (2002) Olivine and S isotopic compositions of the Uitkomst $\mathrm{Ni}-\mathrm{Cu}$ sulfide ore-bearing complex, South Africa: evidence for $\mathrm{S}$ contamination and multiple magma emplacements. Chem Geol 188:149-159

Li C, Ripley EM, Merino E, Maier WD (2004) Replacement of base metal sulphides by actinolite, epidote, calcite and magnetite in the UG2 and Merensky Reef of the Bushveld Complex, South Africa. Econ Geol 99:173-184

Maier WD (2005) Platinum-group element (PGE) deposits and occurrences: mineralization styles, genetic concepts, and exploration criteria. J Afr Earth Sci 41:165-191

Maier WD, Barnes S-J, Gartz V, Andrews G (2003) Pt-Pd reefs in magnetitites of the Stella layered intrusion, South Africa: a world of new exploration opportunities for platinum group elements. Geology 31:885-888

Mavrogenes JA, O'Neill HSC (1999) The relative effects of pressure, temperature and oxygen fugacity on the solubility of sulfide in mafic magmas. Geochim Cosmochim Acta 63:1173-1180
McBirney AR (1989) The Skaergaard layered series: i; structure and average composition. J Petrol 30:363-397

McBirney AR (1996) The Skaergaard Intrusion. In: Cawthorn RG (ed) Layered intrusions. Elsevier, Amsterdam, pp 147-180

McBirney AR, Creaser RA (2003) The Skaergaard layered series, part VII: Sr and Nd isotopes. J Petrol 44:757-771

McDonald AM, Cabri LJ, Rudashevsky NS, Stanley CJ, Rudashevsky VN, Roass KC (2009) Nielsenite, $\mathrm{PdCu}_{3}$, a new platinum-group intermetallic mineral species from the Skaergaard Intrusion, Greenland. Can Mineral 46:709-716

McDonald I, Jones RE, Hughes HSR, Holwell DA, Butler IB (2012) Platinum-group element tenors and S/Se ratios of Platreef sulphide melt inclusions. 5th Platreef workshop, Mokopane, South Africa, Abstr

McKenzie D (2011) Compaction and crystallization in magma chambers; towards a model of the Skaergaard Intrusion. J Petrol 52:905-930

Miller JD, Andersen JCØ (2002) Attributes of Skaergaard-type PGE REEFS. In Boudreau A (ed) Ext abstracts, 9th international platinum symposium, pp 305-308

Miller JD, Green JC, Severson MJ, Chandler VW, Hauck SA, Peterson DM, Wahl TE (2002) Geology and mineral potential of the Duluth Complex and related rocks of northeastern Minnesota. Minnesota Geol Surv Report of Investigations 58:207 pp

Momme P, Tegner C, Brooks CK, Keays RR (2002) The behaviour of platinum-group elements in basalts from the East Greenland rifted margin. Contrib Mineral Petrol 143:133-153

Morse SA (1986) Convection in aid of adcumulus growth. J Petrol 27:1183-1214

Mungall JE (2002) Kinetic controls on the partitioning of trace elements between silicate and sulfide liquids. J Petrol 43:749-768

Mungall JE, Brenan JM (2014) Partitioning of platinum-group elements and $\mathrm{Au}$ between sulfide liquid and basalt and the origins of mantle-crust fractionation of the chalcophile elements. Geochim Cosmochim Acta 125:265-289

Mutanen T (1997) Geology and petrology of the Akanvaara and Koitelainen mafic layered intrusions and Keivitsa-Satovaara layered complex, northern Finland. Geol Surv Finl Bull 395:233

Naldrett AJ (2011) Fundamentals of magmatic sulfide deposits. Revs Econ Geol 17:1-50

Naldrett AJ, Lehmann J (1987) Spinel non-stoichiometry as the explanation for $\mathrm{Ni}-, \mathrm{Cu}-$ and PGE-enriched sulfides in chromitites. In: Prichard HM, Potts PJ, Bowles JWF, Cribb SJ (eds) Geoplatinum '87. Elsevier, London, pp 113-143

Nielsen TFD (2004) The shape and volume of the Skaergaard Intrusion, Greenland: implications for mass balance and bulk composition. J Petrol 45:507-530

Nielsen TFD (2013) Origin of the world-class PGE-Au mineralisation in the Skaergaard intrusion by bulk S-saturation, accumulation, partial dissolution, and secondary reef formation. Geophys Res Abstr 15:EGU2013-7879

Nielsen TFD, Bernstein S (2009) Chemical variations in the Triple Group of the Skaergaard intrusion: insights for the mineralization and crystallization process. Eos Trans. AGU, 90(52), Fall Meet Suppl, Abstract V21A-1956

Nielsen TFD, Rasmussen H, Rudashevsky NS, Kretzer YL, Rudashevsky VN (2003) PGE and sulphide phases of the precious metal mineralization of the Skaergaard intrusion, part 1: sample 90-23A, 807. Danmarks og Grønlands Geologiske Undersøgelse Rapport 2003(47):45p

Nielsen TFD, Andersen JCØ, Brooks CK (2005) The Platinova Reef of the Skaergaard Intrusion. In: Mungall JE (ed) Exploration for platinum-group element deposits. Mineral Assoc Can Short Course Ser 35:431-456 
Nielsen TFD, Andersen JCØ, Holness MB, Keiding JK, Rudashevsky NS, Rudashevsky VN, Salmonsen LP, Tegner C, Veksler IV (2015) The Skaergaard PGE and gold deposit: the result of in situ fractionation, sulphide saturation, and magma chamberscale precious metal redistribution by immiscible Fe-rich melt. J Petrol 56:1643-1676

Ohnenstetter M, Johan Z, Cocherie A, Fouillac AM, Guerrot C, Ohnenstetter D, Chaussidon M, Rouer O, Makovicky E, Mackovicky M, Rose-Hansen J, Karup-Moller S, Vaughan DJ, Turner G, Pattrick RAD, Gize AP, Lyon IC, McDonald I (1999) New exploration methods for platinum and rhodium deposits poor in base metal sulphides-NEXTPRIM. Appl Earth Sci Trans Inst Min Metall 108:B119-B150

Peach CL, Mathez EA, Keays RR (1990) Sulfide melt-silicate melt distribution coefficients for the noble metals and other chalcophile metals as deduced from MORB: implications for partial melting. Geochim Cosmochim Acta 54:3379-3389

Piña R, Gervilla F, Barnes S-J, Ortega L, Lunar R (2013) Platinumgroup elements-bearing pyrite from the Aguablanca $\mathrm{Ni}-\mathrm{Cu}$ sulphide deposit (SW Spain): a LA-ICP-MS study. Eur J Mineral 25:241-252

Prendergast MD (2000) Layering and precious metals mineralization in the Rincón del Tigre Complex, Eastern Bolivia. Econ Geol 95:113-130

Prendergast MD, Keays RR (1989) Controls of platinum-group element mineralization and the origin of the PGE-rich Main Sulfide Zone in the Wedza Subchamber of the Great Dyke, Zimbabwe: implications for the genesis of, and exploration for, stratiform PGE mineralization in layered intrusions. In: Prendergast MD, Jones MJ (eds) Magmatic sulfides - the Zimbabwe volume. Inst Min Miner, London, pp 43-69

Prichard HM, Knight RD, Fisher PC, McDonald I, Zhou M-F, Wang CY (2013) Distribution of platinum-group elements in magmatic and altered ores in the Jinchuan intrusion, China: an example of selenium remobilization by post magmatic fluids. Mineral Depos 48:767-786

Queffurus M, Barnes S-J (2015) Processes affecting the sulfur to selenium ratio in magmatic nickel-copper and platinum-group element deposits. Ore Geol Revs 69:301-324

Ripley EM, Brophy JG, Li C (2002) Copper solubility in a basaltic melt and sulfide liquid/silicate melt partition coefficients of $\mathrm{Cu}$ and Fe. Geochim Cosmochim Acta 66:2791-2800

Ripley EM, Lightfoot PC, Li C, Elswick ER (2003) S isotopic studies of continental flood basalts in the Noril'sk region: implications for the association between lavas and ore-bearing intrusions. Geochim Cosmochim Acta 67:2805-2817

Rudashevsky NS, McDonald AM, Cabri LJ, Nielsen TFD, Stanley CJ, Kretser YL, Rudashevsky VN (2004) Skaergaardite, PdCu, a new platinum-group intermetallic mineral from the Skaergaard Intrusion, Greenland. Mineral Mag 68:615-632

Rudashevsky NS, Kretser YL, Rudashevsky VN, Nielsen TFD (2009) Gold, PGE and sulfide phases of the precious metal mineralization of the Skaergaard intrusion. Part 6: sample 90-23A Danmarks og Grønlands Geologiske Undersøgelse Rapport 798:45 p
Rudashevsky NV, Rudashevsky VN, Nielsen TFD, Shebanov AD (2014) $\mathrm{Au}-\mathrm{Cu}$ alloys and inter-metallides in $\mathrm{Pd}-\mathrm{Au}$ ores of the Skaergaard massif. Proc Russ Mineral Soc 143:1-23

Rudashevsky NV, Rudashevsky VN, Nielsen TFD (2015) Intermetallides and alloys of copper and palladium in ores of the Skaergaard massif. Proc Russ Mineral Soc 144:30-53

Salmonsen LP, Tegner C (2013) Crystallization sequence of the upper border series of the Skaergaard intrusion: revised subdivision and implications for chamber-scale magma homogeneity. Contrib Mineral Petrol 165:1155-1171

Saunders AD, Fitton JG, Kerr AC, Norry MJ, Kent RW (1997) The North Atlantic Igneous Province. In: Mahoney JJ, Coffin MF (eds) Large igneous provinces: continental, oceanic and planetary flood volcanism. Geophysical Monograph 100, American Geophysical Union, Washington DC, pp 45-93

Smith JW, Holwell DA, McDonald I (2014) Precious and base metal geochemistry and mineralogy of the grasvally norite-pyroxenite-anorthosite (GNPA) member, northern Bushveld Complex, South Africa: implications for a multistage emplacement. Mineral Depos 49:667-692

Svennevig K, Guarnieri P (2012) From 3D mapping to 3D modelling: a case study from the Skaergaard intrusion, southern East Greenland. Geol Surv Den Greenl Bull 26:57-60

Tegner C, Cawthorn RG (2010) Iron in plagioclase in the Bushveld and Skaergaard intrusions: implications for iron contents in evolving basic magmas. Contrib Mineral Petrol 159:719-730

Tegner C, Duncan RA, Bernstein S, Brooks CK, Bird DK, Storey M (1998) ${ }^{40} \mathrm{Ar}-{ }^{39} \mathrm{Ar}$ geochronology of tertiary mafic intrusions along the East Greenland rifted margin: relation to flood basalts and the Iceland hotspot track. Earth Planet Sci Lett 156:75-88

Tegner C, Thy P, Holness MB, Jakobsen JK, Lesher CE (2009) Differentiation and compaction in the Skaergaard Intrusion. J Petrol 50:813-840

Thy P, Lesher CE, Tegner C (2009) The Skaergaard liquid line of descent revisited. Contrib Mineral Petrol 157:735-747

Tredoux M, Lindsay NM, Davies G, McDonald I (1995) The fractionation of platinum-group elements in magmatic systems, with the suggestion of a novel causal mechanism. S Afr J Geol 98:157-167

Veksler IV (2009) Extreme iron enrichment and liquid immiscibility in mafic intrusions: experimental evidence revisited. Lithos 111:72-82

Wager LR, Brown GM (1968) Layered igneous rocks. Oliver and Boyd, Edinburgh

Wager LR, Deer WA (1939) Geological investigations in East Greenland: part III. The petrology of the Skaergaard Intrusion, Kangerdlugssuaq, East Greenland. Meddel Grønland, 105:352 pp

Wohlgemuth-Ueberwasser C, Fonseca R, Ballhaus C, Berndt J (2013) Sulfide oxidation as a process for the formation of copper-rich magmatic sulfides. Mineral Depos 48:115-127

Wotzlaw J-F, Bindemana IN, Schalteggera U, Brooks CK, Naslund HR (2012) High-resolution insights into episodes of crystallization, hydrothermal alteration and remelting in the Skaergaard intrusive complex. Earth Planet Sci Lett 355-356:199-212 